\title{
Study of the unknown HONO daytime source at a European suburban site during the MEGAPOLI summer and winter field campaigns
}

\author{
V. Michoud ${ }^{1}$, A. Colomb ${ }^{2}$, A. Borbon ${ }^{1}$, K. Miet ${ }^{1}$, M. Beekmann ${ }^{1}$, M. Camredon ${ }^{1}$, B. Aumont ${ }^{1}$, S. Perrier ${ }^{1,3}$, P. Zapf ${ }^{1}$, \\ G. Siour $^{1}$, W. Ait-Helal ${ }^{1,4,5}$, C. Afif ${ }^{1,6}$, A. Kukui ${ }^{7,8}$, M. Furger ${ }^{9}$, J. C. Dupont ${ }^{10}$, M. Haeffelin ${ }^{10}$, and J. F. Doussin ${ }^{1}$ \\ ${ }^{1}$ LISA, UMR-CNRS 7583, Université Paris Est Créteil (UPEC), Université Paris Diderot (UPD), Institut Pierre Simon \\ Laplace (IPSL), Créteil, France \\ ${ }^{2}$ LaMP, UMR-CNRS 6016, Clermont Université, Université Blaise Pascal, Aubière, France \\ ${ }^{3}$ ISA, UMR-CNRS 5280, Université Lyon 1, ENS-Lyon, Villeurbanne, France \\ ${ }^{4}$ Université Lille Nord de France, Lille, France \\ ${ }^{5}$ Department of Chemistry and Environment, Ecole des Mines de Douai, Douai, France \\ ${ }^{6}$ Centre d'Analyses et de Recherche, Faculty of sciences, Université Saint Joseph, Beirut, Lebanon \\ ${ }^{7}$ LATMOS, UMR-CNRS 8190, Université de Versailles Saint Quentin, Université Pierre et Marie Curie, Guyancourt, France \\ ${ }^{8}$ LPC2E, UMR-CNRS 6115, Orléans, France \\ ${ }^{9}$ Laboratory of Atmospheric Chemistry, Paul Scherrer Institut, Villigen, Switzerland \\ ${ }^{10}$ Institut Pierre Simon Laplace (IPSL), Palaiseau, France
}

Correspondence to: J. F. Doussin (jean-francois.doussin@lisa.u-pec.fr)

Received: 12 July 2013 - Published in Atmos. Chem. Phys. Discuss.: 10 September 2013

Revised: 21 January 2014 - Accepted: 10 February 2014 - Published: 19 March 2014

\begin{abstract}
Nitrous acid measurements were carried out during the MEGAPOLI summer and winter field campaigns at SIRTA observatory in Paris surroundings. Highly variable HONO levels were observed during the campaigns, ranging from $10 \mathrm{ppt}$ to $500 \mathrm{ppt}$ in summer and from $10 \mathrm{ppt}$ to $1.7 \mathrm{ppb}$ in winter. Significant HONO mixing ratios have also been measured during daytime hours, comprised between some tenth of ppt and $200 \mathrm{ppt}$ for the summer campaign and between few ppt and $1 \mathrm{ppb}$ for the winter campaign. Ancillary measurements, such as $\mathrm{NO}_{\mathrm{x}}, \mathrm{O}_{3}$, photolysis frequencies, meteorological parameters (pressure, temperature, relative humidity, wind speed and wind direction), black carbon concentration, total aerosol surface area, boundary layer height and soil moisture, were conducted during both campaigns. In addition, for the summer period, $\mathrm{OH}$ radical measurements were made with a CIMS (Chemical Ionisation Mass Spectrometer). This large dataset has been used to investigate the HONO budget in a suburban environment. To do so, calculations of HONO concentrations using PhotoStationary State (PSS) approach have been performed, for daytime hours.
\end{abstract}

The comparison of these calculations with measured HONO concentrations revealed an underestimation of the calculations making evident a missing source term for both campaigns. This unknown HONO source exhibits a bell-shaped like average diurnal profile with a maximum around noon of approximately $0.7 \mathrm{ppb} \mathrm{h}^{-1}$ and $0.25 \mathrm{ppbh}^{-1}$, during summer and winter respectively. This source is the main HONO source during daytime hours for both campaigns. In both cases, this source shows a slight positive correlation with $J\left(\mathrm{NO}_{2}\right)$ and the product between $J\left(\mathrm{NO}_{2}\right)$ and soil moisture. This original approach had, thus, indicated that this missing source is photolytic and might be heterogeneous occurring at ground surface and involving water content available on the ground. 


\section{Introduction}

The hydroxyl radical $(\mathrm{OH})$ is the main oxidant of the troposphere during daytime (Levy, 1972). It plays a crucial role in the chemical transformations occurring in the troposphere. A major source of $\mathrm{OH}$ radicals is the photolysis of nitrous acid in the near ultraviolet spectral region (R1). This source may even be the main $\mathrm{OH}$ source during the early morning hours (Platt et al., 2002; Alicke et al., 2003). OH radicals formed through this reaction may initiate and accelerate the photochemistry. Nitrous acid is, therefore, an essential species for the chemistry of the troposphere.

$\mathrm{HONO}+h v \rightarrow \mathrm{OH}+\mathrm{NO}$

In earlier studies, this reaction had been considered as a significant radical source just after sunrise only (Lammel and Cape, 1996; Alicke et al., 2003), but more recently it has been shown that it can also be important all over daytime hours (Neftel et al., 1996; Ren et al., 2003, 2006; Dusanter et al., 2009; Michoud et al., 2012) as unexpectedly high HONO levels were observed by chemical techniques during daytime (Zhou et al., 2002; Ren et al., 2003; Kleffmann et al., 2005, 2006; Su et al., 2008; Elshorbany et al., 2009; Li et al., 2012; Wong et al., 2012). Additional observations using optical methods as DOAS (Differential Optical Absorption Spectroscopy) (Acker et al., 2006a; Kleffmann, 2006) confirmed the fact that these high diurnal HONO concentrations were not due to interferences or artifacts of the chemical measurement techniques, although a controversy remains on reliability of chemical measurement techniques (Liao et al., 2006).

Despite its importance, the HONO chemistry is not well established and its formation mechanism remains quite uncertain (Kleffmann, 2007). The high diurnal HONO concentrations recently observed in many environments cannot be explained by its known sources. This indicates that one or several unknown HONO sources exist.

HONO is emitted directly into the atmosphere through combustion processes, due to traffic or biomass burning. Indeed, numerous studies have observed direct emission of HONO from vehicles exhaust (Kirchstetter et al., 1996; Kurtenbach et al., 2001; Y. Q. Li et al., 2008) characterised by low $\mathrm{HONO} / \mathrm{NO}_{\mathrm{x}}$ ratio, typically less than $1 \%(0.2 \%$ to $0.8 \%$ depending on the type of vehicles, emission control technologies, etc....). In addition, HONO is directly emitted from biomass burning as observed by Park et al. (2004) and Veres et al. (2010). The latter study has observed an emission of $\mathrm{HONO}$ during laboratory biomass fires with a $\mathrm{HONO} / \mathrm{CO}$ ratio between $1.2 \times 10^{-3}$ and $4.6 \times 10^{-3} \mathrm{~mol} \mathrm{~mol}^{-1} \mathrm{CO}$ depending on the fuels used.

HONO can also be formed through gas-phase or heterogeneous reactions. The main homogeneous gas-phase reaction during daytime leading to HONO formation is the reaction between $\mathrm{OH}$ and $\mathrm{NO}$ (Reaction R2) which needs a third body reactant $(\mathrm{M})$.

$\mathrm{NO}+\mathrm{OH}(+\mathrm{M}) \rightarrow \mathrm{HONO}(+\mathrm{M})$

Other gas-phase reactions forming HONO have been proposed such as the reaction between $\mathrm{NO}_{2}$ and $\mathrm{HO}_{2}$ (Stockwell and Calvert, 1983) or the reaction between excited nitrogen dioxide $\left(\mathrm{NO}_{2}^{*}\right)$ and a molecule of water ( $\mathrm{S}$. Li et al., 2008) which leads also to the formation of an $\mathrm{OH}$ radical. However, these reactions are expected to be of minor importance under real atmospheric conditions (Sörgel et al., 2011a; Wong et al., 2012). Reaction between $\mathrm{NO}_{2}$ and $\mathrm{HO}_{2}$ has even been excluded by Tyndall at al. (1995). Also, the $\mathrm{OH}$ and $\mathrm{HONO}$ source from $\mathrm{NO}_{2}^{*}+\mathrm{H}_{2} \mathrm{O}$ has been recently disqualified for atmospheric conditions by Amedro et al. (2011).

In addition to these gas-phase HONO formation pathways, many heterogeneous reactions on aerosols or at the ground have been proposed (Ammann et al., 1998; Kalberer et al., 1999; Zhou et al., 2001, 2002, 2003; George et al., 2005; Stemmler et al., 2006; Su et al., 2011). It is now generally assumed that heterogeneous conversion of $\mathrm{NO}_{2}$ on humid surfaces is the main HONO formation pathway in the nocturnal boundary layer (Kleffmann, 2007). However, the mechanism responsible for this HONO source is still under discussion and it seems that this conversion depends on the surface where it takes place (Kleffmann, 2007). One of the mechanisms proposed is the $\mathrm{NO}_{2}$ dismutation on a wet surface (Reaction R3), which has been observed during laboratory studies (Finlayson-Pitts et al., 2003).

$2 \mathrm{NO}_{2}+\mathrm{H}_{2} \mathrm{O} \rightarrow \mathrm{HONO}+\mathrm{HNO}_{3}$

Besides its stoichiometry, this reaction is known to be first order for $\mathrm{NO}_{2}$ (Jenkin et al., 1988) and to be dependent on relative humidity which is supposed to be representative of the quantity of water on the surfaces where the reaction can take place (Lammel and Cape, 1996; Finlayson-Pitts et al., 2003).

A heterogeneous reduction of $\mathrm{NO}_{2}$ on soot surfaces leading to HONO formation has also been observed (Amman et al., 1998) (Reaction R4). Kalberer et al. (1999) have also reported that this reaction depends on relative humidity.

$\mathrm{NO}_{2}+\mathrm{red}_{\mathrm{ads}} \rightarrow \mathrm{HONO}+\mathrm{Ox}_{\mathrm{ads}}$

Nevertheless, some studies have demonstrated that this reaction cannot explain the HONO levels observed in the atmosphere due to a too low yield (Kleffmann et al., 1999) or because reactive sites at the soot surfaces are likely to undergo saturation during soot ageing (Kalberer et al., 1999; Kleffmann et al., 1999). A modelling study taking into account the deactivation of the reactive sites during soot ageing has shown that Reaction (R4) cannot explain HONO formation in the atmosphere, unless a fast reactivation process of soot surface exists (Aumont et al., 1999).

Other heterogeneous HONO formation reactions have been proposed to explain correlations found between HONO 
and NO in the nocturnal atmosphere (Calvert et al., 1994; Saliba et al., 2000), such as the reactions between NO and $\mathrm{NO}_{2}$ or between $\mathrm{NO}$ and $\mathrm{HNO}_{3}$ on surfaces. Nevertheless, other studies have shown that these two reactions were not important under atmospheric conditions (Kleffmann et al., 1998, 2004; Kleffmann and Wiesen, 2005).

In order to explain high HONO levels during daytime hours, laboratory or field studies (Zhou et al., 2001, 2002) have proposed the photolysis of nitric acid $\left(\mathrm{HNO}_{3}\right)$ adsorbed on the ground as a missing source of HONO. It is well known that $\mathrm{HNO}_{3}$ is a sticky molecule and that its deposition is its main sink (Finlayson-Pitts and Pitts, 2000). $\mathrm{HNO}_{3}$ can, thus, accumulate on the ground in absence of precipitation. Once exposed to sunlight, this adsorbed $\mathrm{HNO}_{3}$ can be photolysed leading to HONO formation in the presence of water as a byproduct of a chemical mechanism (Reactions R5-R7) (Zhou et al., 2003). Adsorbed HONO formed through this mechanism can, then, desorb into the gas-phase.

$\mathrm{HNO}_{3(\mathrm{ads})}+h v \rightarrow \mathrm{HNO}_{3}{ }^{*}{ }^{(\mathrm{ads})}$

$\mathrm{HNO}_{3 *(\mathrm{ads})} \rightarrow \mathrm{HNO}_{2(\mathrm{ads})}+\mathrm{O}\left({ }^{3} \mathrm{P}\right)_{(\mathrm{ads})}$

$\mathrm{HNO}_{3 \text { (ads) }}^{*} \rightarrow \mathrm{NO}_{2(\text { ads })}+\mathrm{OH}_{(\mathrm{ads})}$

$2 \mathrm{NO}_{2(\text { ads })}+\mathrm{H}_{2} \mathrm{O}_{(\mathrm{ads})} \rightarrow \mathrm{HONO}_{(\mathrm{ads})}+\mathrm{HNO}_{3(\mathrm{ads})}$

It is, however, still unclear why the $\mathrm{HNO}_{3}$ photolysis frequency proposed by Zhou et al. (2003) is two orders of magnitude larger than the $\mathrm{HNO}_{3}$ photolysis frequencies in the aqueous-phase or in the gas-phase.

Recently, Su et al. (2011) have illustrated that nitrites, formed through biological processes in the soil, can be a source of HONO through Reaction (R8).

$\mathrm{NO}_{2}^{-}(\mathrm{aq})+\mathrm{H}^{+}(\mathrm{aq}) \rightarrow \mathrm{HONO}_{(\mathrm{aq})}$

Aqueous HONO formed by this process can then desorb into the gas-phase. Obviously, this reaction depends on many parameters such as soil $\mathrm{pH}$, nitrite concentration in soil, soil water content and soil temperature but is light independent.

Other heterogeneous and light-dependent sources of $\mathrm{HONO}$ have been observed such as the reduction of $\mathrm{NO}_{2}$ into HONO on organic surfaces such as humic acids (Stemmler et al., 2006) or aromatic compounds (George et al., 2005).

Finally, in addition to direct emission, homogeneous gasphase formation and heterogeneous reactions, a study has highlighted the fact that ortho-nitrophenols photolysis may be responsible for HONO formation (Bejan et al., 2006). Indeed, in urban conditions, the authors have estimated a production of $\mathrm{HONO}$ at noon through these reactions of $100 \mathrm{ppth}^{-1}$. They also proposed the photolysis of methylsubstituted nitro aromatics as additional HONO sources.

Therefore, it appears that the nature of the missing source remains unclear. Some studies have investigated the daytime HONO vertical profiles in order to solve this issue (Veitel et al., 2002; Kleffmann et al., 2003; Häseler et al., 2009; Zhang et al., 2009; Sörgel et al., 2011b; Villena et al., 2011; Wong et al., 2012). Indeed, if the missing source is occurring on ground (heterogeneous reaction on ground and/or soil emission), one could expect the existence of a strong vertical gradient in HONO concentrations. On the contrary, the absence of a vertical gradient in HONO concentrations could be expected with a source occurring all along the atmospheric column (gas phase reaction and/or heterogeneous reaction on aerosol surface). However, no clear tendency was found regarding these studies, since a vertical gradient is sometimes observed (Veitel et al., 2002; Zhang et al., 2009; Villena et al., 2011; Wong et al., 2012) and sometimes not (Häseler et al., 2009).

While high uncertainties persist about HONO formation processes, the losses of HONO are well understood. The main sink of HONO during the day is its photolysis (Reaction R1). This process drives the HONO level during the day leading to low HONO concentrations and then an accumulation during the night when it stops. The reaction between $\mathrm{OH}$ and HONO (Reaction R9) is another sink of HONO occurring mainly during the day. However, this sink is much less efficient than HONO photolysis (see Supplement S1).

$\mathrm{OH}+\mathrm{HONO} \rightarrow \mathrm{H}_{2} \mathrm{O}+\mathrm{NO}_{2}$

Other gas-phase reactions, i.e. dismutation $(\mathrm{HONO}+\mathrm{HONO})$ and reaction between $\mathrm{HONO}$ and $\mathrm{HNO}_{3}$ are negligible since they are too slow under atmospheric conditions (Kleffmann, 2007). Finally, the main HONO sink during the night is its dry deposition whose velocity ranges from 0.077 to $3 \mathrm{~cm} \mathrm{~s}^{-1}$ (Stutz et al., 2002) over grass surfaces.

A previous study, conducted at a suburban site in the surrounding of Paris, has shown that HONO photolysis represents the main radical source with an averaged raw contribution of approximately $35 \%$ to the total radical initiation during the summer campaign (Michoud et al., 2012). This high contribution of HONO photolysis to radical initiation has motivated a more advanced study of HONO chemistry in this environment both in summer and winter seasons. This study will provide some new insights into the identification of the known and possible missing HONO sources in Paris surrounding. The present work is based on the comparison between observed and calculated HONO concentrations using Photo Stationary State calculations (PSS). The unknown HONO source is calculated using the difference between observed and calculated HONO concentrations based on known reactions. This missing source is then compared to various parameters to identify plausible formation processes. 


\section{The MEGAPOLI experiment}

All the measurements used and presented in this study have been collected in the framework of the MEGAPOLI (Megacities: Emissions, urban, regional and Global Atmospheric POLlution and climate effects, and Integrated tools for assessment and mitigation) summer and winter campaigns. These campaigns took place at several ground sites during the whole month of July 2009 and between 15 January and 15 February 2010, respectively (Freutel et al., 2013; Zhang et al., 2013). In addition, several mobile vans (Crippa et al., 2013) and a research aircraft were also deployed. In this study, we focus on the data collected at the SIRTA ("Site Instrumental de Recherche par Télédétection Atmosphérique") observatory (Haeffelin et al., 2005; Pietras et al., 2007) which is a French platform dedicated to cloud and aerosol research at Palaiseau in the "Ecole Polytechnique" area $\left(48.718^{\circ} \mathrm{N}\right.$, $2.207^{\circ} \mathrm{E}$ ), $14 \mathrm{~km}$ southwest of Paris (France) in a semi-urban environment (Freutel et al., 2013). Thus, this site is downwind of Paris under anticyclonic conditions with north and northeasterly winds and receives clean oceanic air masses from west of France the rest of the time (Freutel et al., 2013). The site is surrounded by fields to the west and northwest, by suburban towns in other directions and by highways and secondary roads in all directions. Furthermore the direct vicinity of the site is composed of quite homogeneous surfaces with mainly grass lands.

An overall description of gaseous compounds and parameters measured during this campaign has already been given in Michoud et al. (2012) for the summer campaign. Here we briefly describe essential measurements used in this study and differences between the two campaigns.

\subsection{HONO measurements}

Nitrous acid (HONO) was measured by an instrument (NitroMAC) based on a wet chemical derivatization technique. This instrument is based on the principle displayed by Huang et al. (2002) and has been described in detail in Afif et al. (2014) including also an intercomparison with a LOPAP instrument in the latter study. Here we briefly present the measurement technique and essential details about the setup and performance of the system during the MEGAPOLI campaigns.

The air sampled through a sampling line is pulled by a vacuum pump controlled by a mass flow controller at $2 \mathrm{~L} \mathrm{~min}^{-1}$ flow into two 20 -turn coils in a series. The temperature of these coils is thermostated by Peltier effect, avoiding changes in trapping efficiency. HONO is collected, with a trapping efficiency of $99.99 \%$ (Afif, 2008), thanks to a phosphate buffer solution at $\mathrm{pH} 7$ circulating into the two stripping coils at a flow rate of $0.18 \mathrm{~mL} \mathrm{~min}^{-1}$. The totality of the HONO is sampled into the first coil, and thus, only chemical species possibly causing interferences are sampled into the second coil. The interfering species sampled this way are supposed to be trapped in equal quantity in the first and the second coil because of their low trapping efficiencies. After the sampling, the solutions pass through a debubbler, to eliminate the gas carried in excess. The solutions are then derivatized using an aqueous sulphanilamide/ N-(1-naphthyl)-ethylenediamine solution (SA/NED: $4 \times 10^{-3} \mathrm{M} / 4 \times 10^{-4} \mathrm{M}$ and $\mathrm{HCl}$ at $48.10^{-3} \mathrm{M}$ to form the azo-dye). The derivatization reaction takes place mostly in a 7-minutes loop which is thermostated at $55^{\circ} \mathrm{C}$ to accelerate the derivatization kinetics. Finally, the detection is performed by absorption at $540 \mathrm{~nm}$, after HPLC separation.

The HPLC system consists of a JASCO PU2089 pump, a 10-port electrically activated auto-injection Valco valve with two $300 \mu \mathrm{L}$ sample loops, a C18 guard cartridge (Alltech, $3 \mu \mathrm{m}, 4.6 \times 7.5 \mathrm{~mm}$ ), and a JASCO UV2070 UV-visible absorption detector. The mobile phase is composed of $25 \%$ acetonitrile in water with $15 \mathrm{mM} \mathrm{HCl}$ and the flow rate is $0.7 \mathrm{~mL} \mathrm{~min}^{-1}$. The samples are loaded alternatively into the sample loop and injected into the HPLC system. The analysis time is $5 \mathrm{~min}$ for each coil. In order to obtain responses for both channels at the same time, a 5 min waiting loop was installed for the second channel upstream of the injection valve. The system is automated by using a PC-based HPLC data system. The response obtained for the second channel is then subtracted from that of the first channel to eliminate interferences. The time resolution is therefore $10 \mathrm{~min}$. The one-sigma relative error for HONO concentration estimated is around $6 \%$. Finally, this instrument was calibrated before and after each campaign using nitrite liquid solutions at different concentrations.

\subsection{Other measurements}

All measurements are listed in Table 1. Meteorological parameters such as relative humidity (RH), temperature, pressure, wind speed and wind direction have been measured using a meteorological station (Young ${ }^{\circledR}$ ) installed at the top of a $9 \mathrm{~m}$ mast. The boundary layer height was derived from vertical profiles of aerosol backscattered light measured during both campaigns using a near-zenith pointing Leosphere ALS450 Lidar as described in Haeffelin et al. (2012). The photolysis frequencies have been measured using two filter radiometers, for $J\left(\mathrm{NO}_{2}\right)$ and $J\left(\mathrm{O}^{1} \mathrm{D}\right)$ measurements, and a spectroradiometer (LI-1800) for $J(\mathrm{HONO})$ measurements. Details about the setup, the performances and the estimated uncertainty have been presented elsewhere for the MEGAPOLI summer campaign (Michoud et al., 2012) and are also valid for the winter campaign as no modification was added for this last campaign.

The $\mathrm{OH}$ radicals have been measured, during the summer campaign only, using chemical ionisation mass spectrometry (CIMS) (Eisele and Tanner, 1991; Tanner et al., 1997; Berresheim et al., 2000). A detailed description of the instrument was presented elsewhere (Kukui et al., 2008) as well as the essential details about the setup and performance of the 
Table 1. Measurements and techniques deployed during the MEGAPOLI campaigns at SIRTA observatory.

\begin{tabular}{|c|c|c|c|}
\hline Species & $\begin{array}{r}\text { Time resolution ( } \mathrm{min}) \\
/ 2 \sigma \text { uncertainties }(\%) \\
/ \text { detection limit }\end{array}$ & Instrumentation & Institution \\
\hline $\mathrm{OH}$ & $5 / 35 / 3.10^{5} \mathrm{~cm}^{-3}$ & CIMS SAMU-only summer & LATMOS \\
\hline NO & $1 / 5 / 0.5 \mathrm{ppb}$ & Ozone chemiluminescence & LISA \\
\hline $\mathrm{NO}_{2}$ & $1 / 5 / 0.5 \mathrm{ppb}$ & Luminol chemiluminescence & LISA \\
\hline $\mathrm{O}_{3}$ & $1 / 5 / 1 \mathrm{ppb}$ & UV absorption & LISA \\
\hline HONO & $10 / 12 / 5-10 \mathrm{ppt}$ & $\begin{array}{l}\text { Wet chemical derivatization (SA/NED)/ } \\
\text { HPLC detection (NitroMAC) }\end{array}$ & LISA \\
\hline Photolysis frequencies $J\left(\mathrm{NO}_{2}\right), J(\mathrm{HONO})$ & $1-10 / 20-25 / 10^{-7}-5.10^{-5} \mathrm{~s}^{-1}$ & Filterradiometre, spectroradiometre (LI-1800) & LISA \\
\hline $\mathrm{RH}$, temperature, pressure, wind speed, wind direction & $1 / \mathrm{nc} / \mathrm{nc}$ & Wind sensor and multiplate radiation shield (Young) & LISA \\
\hline Boundary layer height & $60 / \mathrm{nc} / \mathrm{nc}$ & Lidar & LMD \\
\hline Soil moisture at $5 \mathrm{~cm}$ below ground surface & $1 / \mathrm{nc} / \mathrm{nc}$ & Soil moisture probe & LMD \\
\hline Aerosol surface & $1 / \mathrm{nc} / \mathrm{nc}$ & Aerodynamic Particle Sizer & PSI \\
\hline
\end{tabular}

system during the MEGAPOLI summer campaign (Michoud et al., 2012).

NO was measured by a commercial analyser model AC31M (Environnement S.A.) using ozone chemiluminescence. This analyser was weekly calibrated using a $200 \mathrm{ppb}$ $\mathrm{NO}$ /Air mixture cylinder during both campaigns. $\mathrm{NO}_{2}$ was measured by a commercial analyser NOxTOy (Metair) using luminol chemiluminescence as described in details by Hasel et al. (2005). Multipoint calibrations $(0-40 \mathrm{ppb})$ of both analysers were carried out before and after each campaign using gas cylinders containing $200 \mathrm{ppb}$ of $\mathrm{NO}$ or $\mathrm{NO}_{2}$ Air mixture and a dilution system. $\mathrm{O}_{3}$ was measured with an UV absorption analyser model 49C (Thermo Environmental). This instrument was calibrated before the summer campaign using a quantified ozone source (ANSYCO). Finally, Aerosol surface was derived from data measured with an Aerodynamic Particle Sizer (APS spectrometer, Model 3321, TSI).

\section{Photo Stationary State (PSS) approach}

At first, a PSS approach was used to determine whether the known chemistry of HONO (sources and sinks) could explain the HONO concentrations observed. In this method, one considers that sources and sinks of reactive species balance each other. This statement is appropriate for species with short lifetime, typically radical species, but can be problematic for species such as HONO with lifetime during the day of about $20 \mathrm{~min}$. Nevertheless, this approach has been widely used (Kleffmann, 2007 and references therein) and allows studying the HONO budget keeping in mind its limits.

During daytime hours, nitrous acid is expected to be at a photo stationary state due to its formation by the reaction between $\mathrm{OH}$ and NO (Reaction R2), its sinks by its photolysis (Reaction R1) and its reaction with OH (Reaction R9). To these sinks, one can add the dry deposition of HONO, which is the main loss process of HONO at night. However, this process is supposed to have a minor contribution during daytime in comparison to HONO photolysis. Considering these sources and sinks, a theoretical HONOPSS concentration can be calculated using Eq. (1):

$$
[\mathrm{HONO}]_{\mathrm{PSS} 1}=\frac{k_{\mathrm{OH}+\mathrm{NO}}[\mathrm{OH}][\mathrm{NO}]}{k_{\mathrm{OH}+\mathrm{HONO}}[\mathrm{OH}]+J(\mathrm{HONO})+\frac{v_{\mathrm{HONO}}}{h}}
$$

$[\mathrm{OH}]$ and $[\mathrm{NO}]$ represent the measured $\mathrm{OH}$ and $\mathrm{NO}$ concentrations, $J(\mathrm{HONO})$ represents the measured HONO photolysis frequencies. $k_{\mathrm{OH}+\mathrm{NO}}$ and $k_{\mathrm{OH}+\mathrm{HONO}}$ represent the rate constants of reactions between $\mathrm{OH}$ and $\mathrm{NO}$ and between $\mathrm{OH}$ and HONO, respectively. These rate constants are pressure and temperature dependent and are calculated using formulas given by Atkinson et al. (2004) and measured temperature and pressure values. $v_{\text {HONO }}$ represents the deposition velocity of HONO, which was set for the calculation at $0.5 \mathrm{~cm} \mathrm{~s}^{-1}$, which corresponds to the highest value given by Stutz et al. (2002). Finally, h represents the measured boundary layer height.

In addition to this well-known HONO source (i.e. homogeneous formation), we adapted the PSS approach by adding other less established processes, such as direct emission and heterogeneous $\mathrm{HONO}$ formation from conversion of $\mathrm{NO}_{2}$ on ground surface and aerosol surfaces. The addition of these processes to HONO concentration calculations takes into account suspected processes leading to HONO formation. Thus, we obtained the following equation for the calculation of HONO concentrations:

$$
\begin{aligned}
& {[\mathrm{HONO}]_{\mathrm{PSS} 2}=} \\
& \frac{k_{\mathrm{OH}+\mathrm{NO}}[\mathrm{OH}][\mathrm{NO}]+0.03\left[\mathrm{NO}_{2}\right] \frac{v_{\mathrm{NO}_{2}}}{h}+\frac{\gamma_{\mathrm{a}} c S}{4}\left[\mathrm{NO}_{2}\right]+\frac{0.008 \cdot E_{\mathrm{NO}_{\mathrm{x}}}}{h}}{k_{\mathrm{OH}+\mathrm{HONO}}[\mathrm{OH}]+J_{\mathrm{HONO}}+\frac{\nu_{\mathrm{HONO}}}{h}}
\end{aligned}
$$

The HONO direct emission is parameterized in Eq. (2) using the emission ratio $\mathrm{HONO} / \mathrm{NO}_{\mathrm{x}}$ of $0.8 \%$ given by Kurtenbach et al. (2001), $\mathrm{NO}_{\mathrm{x}}$ emission factor profile $\left(E_{\mathrm{NO}_{\mathrm{x}}}\right)$ given by the emission inventory from TNO for the MEGAPOLI project (Denier Van der Gon et al., 2009) and measured boundary layer height $(h)$. In this parameterization we assume that there is no vertical gradient for HONO concentrations which is not always verified (see discussion on the gradient in the Sect. 1). Nevertheless, this parameterization 
allows a rough estimation of the emission process. The emission factor profile $\left(E_{\mathrm{NO}_{\mathrm{x}}}\right)$ taken here is the result of the interpolation of the adjacent cells emission profiles (spatial resolution of the cells: $7 \mathrm{~km}$ ) weighted regarding the distance of the measurement site with the centre of the adjacent cells. The heterogeneous conversion of $\mathrm{NO}_{2}$ on the ground surface is parameterized in Eq. (2) using measured $\mathrm{NO}_{2}$ concentrations, a conversion efficiency of $\mathrm{NO}_{2}$ into $\mathrm{HONO}$ of 0.03 given by Stutz et al. (2002) for grass land surface, the $\mathrm{NO}_{2}$ deposition velocity $\left(\nu_{\mathrm{NO}_{2}}=0.1 \mathrm{~cm} \mathrm{~s}^{-1}\right.$, Seinfeld and Pandis, 1998 ) and the measured boundary layer height $(h)$. The use of a single value for the $\mathrm{NO}_{2}$ deposition velocity represents a source of uncertainties since this parameter is supposed to vary during the day. Nevertheless, this parameterization aims at estimates this known but not well characterised process at least in the right order of magnitude. Finally, the heterogeneous conversion of $\mathrm{NO}_{2}$ on aerosol surfaces is parameterized in Eq. (2) using an equation given by Kleffmann et al. (1998), where $\gamma_{\mathrm{a}}$ represents the uptake coefficient of $\mathrm{NO}_{2}$ on aerosol surfaces $\left(\gamma_{\mathrm{a}}=10^{-6}\right), c$ represents the $\mathrm{NO}_{2}$ mean speed, $S$ represents the total aerosol surface area calculated using Aerosol Particle Sizer (APS) data (size range: 0.49$20.53 \mu \mathrm{m})$ and $\left[\mathrm{NO}_{2}\right]$ represents the measured $\mathrm{NO}_{2}$ concentrations.

In addition of the uncertainties displayed before, the lack of vertical mixing in this calculation would also cause additional uncertainties.

Obviously, it was possible to apply this calculation only when all parameters involved in the calculation were available simultaneously. Despite this limitation, calculations could be carried out and compared to observations for eight and fifteen days of the summer and winter campaigns respectively.

While $\mathrm{OH}$ was directly measured in summer, this was not the case in winter. $\mathrm{OH}$ concentrations used to perform the calculations in winter were obtained using a box model. Given the good performance obtained by the model set up by Michoud et al. (2012) for the summer campaign, the same model was used here. It is a OD box model with chemical reactions given by the Master Chemical Mechanism (Saunders et al., 1997; Jenkin et al., 2003; Saunders et al., 2003; Bloss et al., 2005) and constrained with all measured parameters and species concentrations. The modelling procedure used consisted in a spin up approach as described in Michoud et al. (2012) (method 1). The simulated $\mathrm{OH}$ concentrations for the winter campaign are shown in Supplement S3.
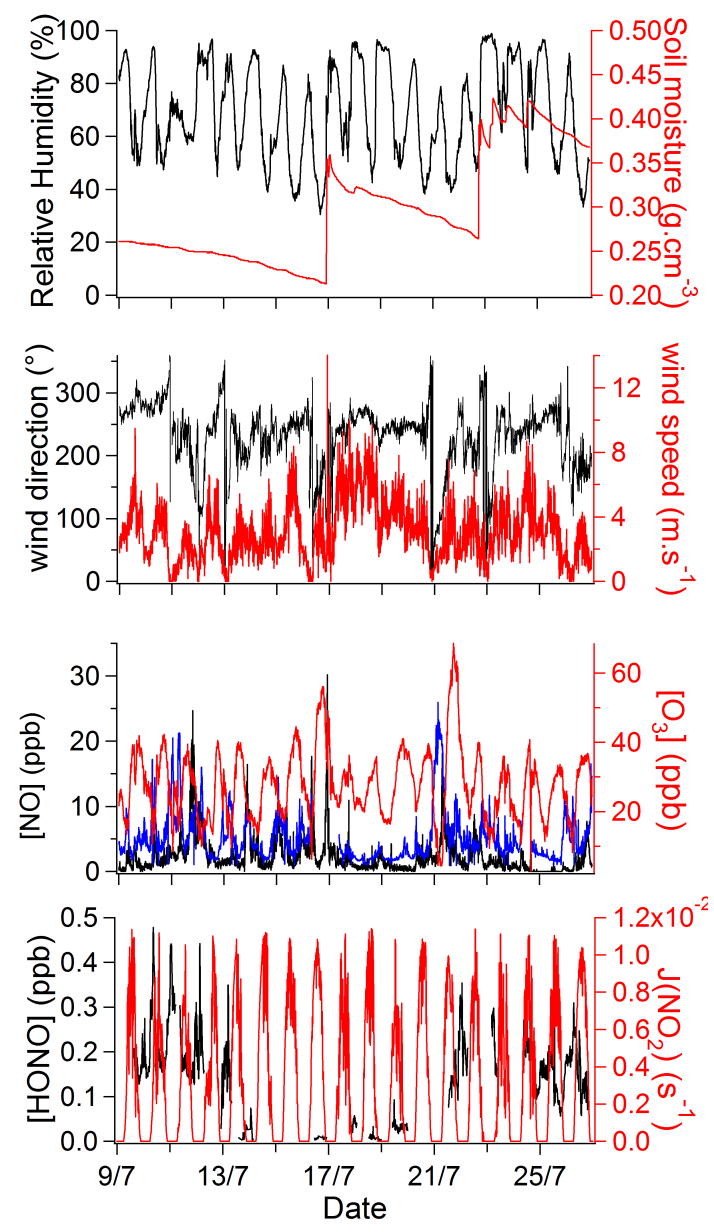

Fig. 1. $10 \mathrm{~min}$ averaged data of relative humidity, soil moisture measured at $5 \mathrm{~cm}$ below ground level, wind direction, wind speed, $\mathrm{NO}_{\mathrm{x}}$, $\mathrm{O}_{3}$, HONO and $J\left(\mathrm{NO}_{2}\right)$ during the MEGAPOLI summer field campaign at the SIRTA observatory, 9-26 July 2009.

\section{Results and discussion}

\subsection{Overview of measurement results}

\subsubsection{The MEGAPOLI summer campaign}

The measured concentrations of inorganic species $\left(\mathrm{NO}_{\mathrm{x}}, \mathrm{O}_{3}\right.$ and $\mathrm{HONO}$ ) as well as measured meteorological parameters $\left(J\left(\mathrm{NO}_{2}\right)\right)$, wind speed, wind direction, relative humidity and soil moisture (measured at $5 \mathrm{~cm}$ below ground surface) between 9-26 July 2009 are shown in Fig. 1. $\mathrm{O}_{3}, \mathrm{NO}_{\mathrm{x}}$ and HONO levels during the MEGAPOLI summer campaign as well as meteorological conditions have been discussed elsewhere (Michoud et al., 2012). The mean diurnal profile of $\mathrm{NO}_{\mathrm{x}}, \mathrm{O}_{3}, \mathrm{HONO}$ and $J\left(\mathrm{NO}_{2}\right)$ averaged every $10 \mathrm{~min}$ over the campaign period are shown in Fig. 2.

During the summer campaign, the measurement site mainly received air masses coming from westerly and southwesterly sectors associated with high wind speed 

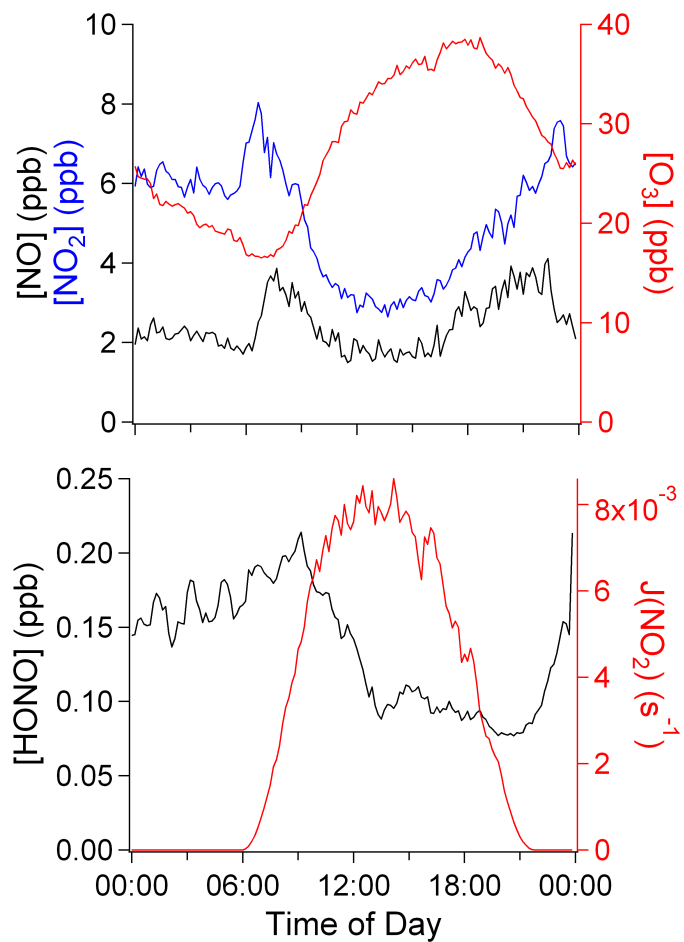

Fig. 2. Average diurnal $10 \mathrm{~min}$ profiles for $\mathrm{O}_{3}, \mathrm{NO}_{\mathrm{x}}, \mathrm{HONO}$, and $J\left(\mathrm{NO}_{2}\right)$ during the MEGAPOLI summer campaign (local time).

(approximately $90 \%$ of the whole time period), with isolated events of air masses coming from the east and southeast sectors (Ait-Helal et al., 2014). These conditions explain quite low pollutant levels observed during this campaign more representative of a regional background, Paris being located northeast of SIRTA observatory.

Ozone shows a typical bell shaped profile with an average maximum of $38 \mathrm{ppb}$ around 17:00 local time (LT). NO and $\mathrm{NO}_{2}$ show also typical profiles with two maxima during morning and afternoon traffic rush hours. The morning maxima are 4 and $8 \mathrm{ppb}$ for $\mathrm{NO}$ and $\mathrm{NO}_{2}$, respectively, at around 07:00-08:00 (LT).

HONO mixing ratios were variable over the full campaign period and reached up to $500 \mathrm{ppt}$ on some days. HONO diurnal profile shows a maximum around 09:00(LT) of about $210 \mathrm{ppt}$, since HONO accumulates during night time. Later during the day, these mixing ratios decrease to about $100 \mathrm{ppt}$ due to fast photolysis of HONO.

\subsubsection{The MEGAPOLI winter campaign}

The measured concentrations of inorganic species $\left(\mathrm{NO}_{\mathrm{x}}, \mathrm{O}_{3}\right.$ and $\mathrm{HONO}$ ) as well as measured meteorological parameters $\left(J\left(\mathrm{NO}_{2}\right)\right)$, wind speed, wind direction, relative humidity and soil moisture (measured at $5 \mathrm{~cm}$ below ground surface) between the 15 January and the 6 February 2010 are shown in Fig. 3 for the MEGAPOLI winter campaign. The aver-
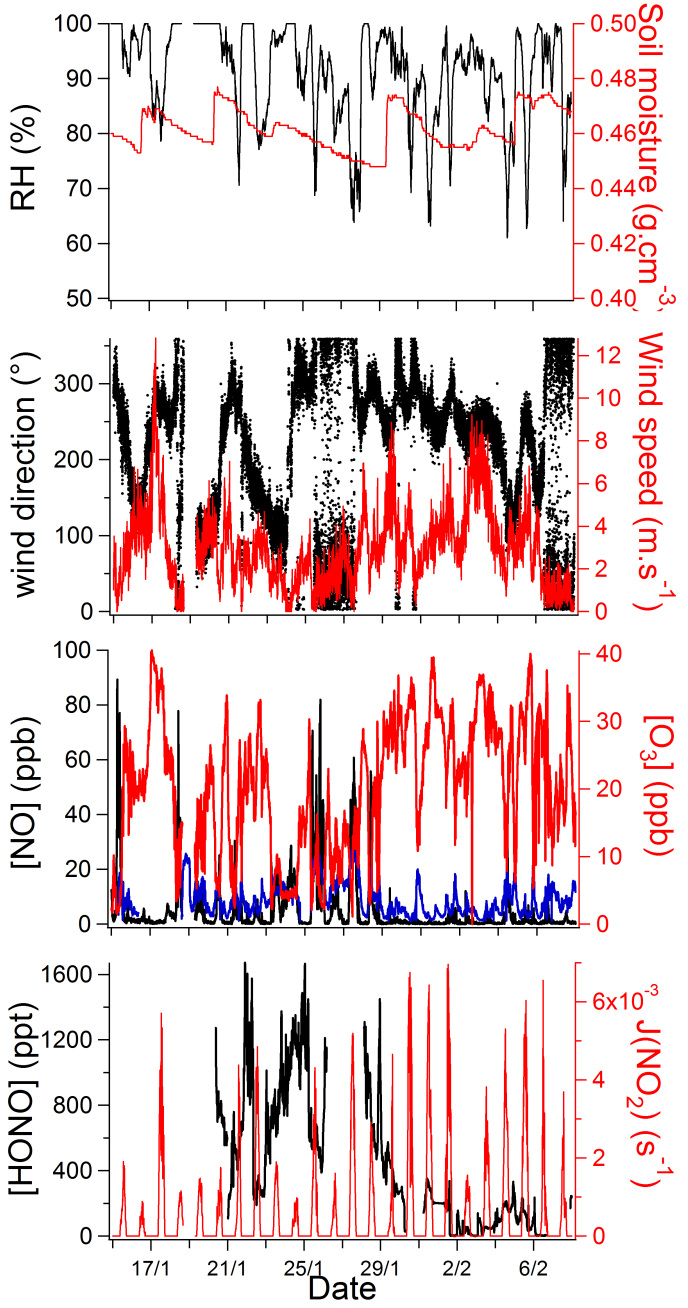

Fig. 3. $10 \mathrm{~min}$ data of relative humidity, soil moisture measured at $5 \mathrm{~cm}$ below ground level, wind direction, wind speed, $\mathrm{NO}_{\mathrm{x}}, \mathrm{O}_{3}$, $\mathrm{HONO}$ and $J\left(\mathrm{NO}_{2}\right)$ during the MEGAPOLI winter field campaign at the SIRTA observatory, 15 January-7 February 2010.

aged diurnal profiles of $\mathrm{NO}_{\mathrm{x}}, \mathrm{O}_{3}, \mathrm{HONO}$ and $J\left(\mathrm{NO}_{2}\right)$ for the MEGAPOLI winter campaign are shown in Fig. 4.

During the MEGAPOLI winter campaign, colder conditions were encountered with temperatures between -6 and $10^{\circ} \mathrm{C}\left(1.8^{\circ} \mathrm{C}\right.$ in average $)$. Some snow events have also been encountered during the campaign, between the 10 February and the 14 February. However, HONO chemistry during these particular events will be discussed in another article. This paper focuses only on the first part of the winter campaign which is free of snow events. As during the summer campaign, the site received mainly air masses from westerly and northwesterly sectors, bringing rather unpolluted air. However, some events with air masses coming from easterly and northeasterly sectors, advecting more continental and polluted air masses which passed above the Paris area before reaching the measurement site, were 

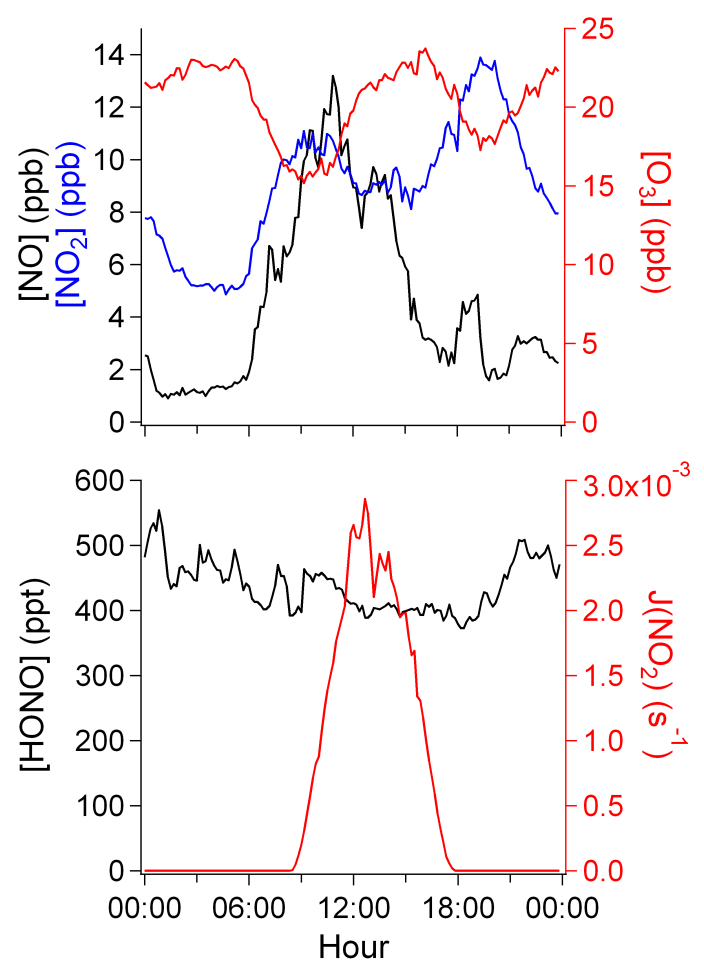

Fig. 4. Average diurnal $10 \mathrm{~min}$ profiles for $\mathrm{O}_{3}, \mathrm{NO}_{\mathrm{x}}, \mathrm{HONO}$, and $J\left(\mathrm{NO}_{2}\right)$ during the MEGAPOLI winter campaign (local time).

encountered (approximately one third of the campaign duration). During these events, high $\mathrm{NO}_{\mathrm{x}}$ mixing ratios were observed, up to $100 \mathrm{ppb}$, while $\mathrm{O}_{3}$ concentration decreased. Measured $J\left(\mathrm{NO}_{2}\right)$ values were approximately three times lower than during the summer campaign. Observed HONO mixing ratios were higher than during the summer campaign, reaching up to $1.7 \mathrm{ppb}$ for some days. These differences between the summer and winter can be explained by the lower photolysis frequency in winter, photolysis being the major HONO sink, as well as by a stronger temperature inversion in winter than in summer leading to a lower boundary layer height in winter.

Ozone presents no clear diurnal profile with mixing ratios measured at noon close to mixing ratios observed at night (around 20-25 ppb). NO presents a diurnal profile with a maximum of around $13 \mathrm{ppb}$ in the morning, while $\mathrm{NO}_{2} \mathrm{ex}-$ hibits a diurnal profile with two maxima, one in the morning and the other in the evening, of approximately 10$14 \mathrm{ppb}$. Averaged HONO mixing ratios remain almost constant (around 400-500 ppt) all over the day.

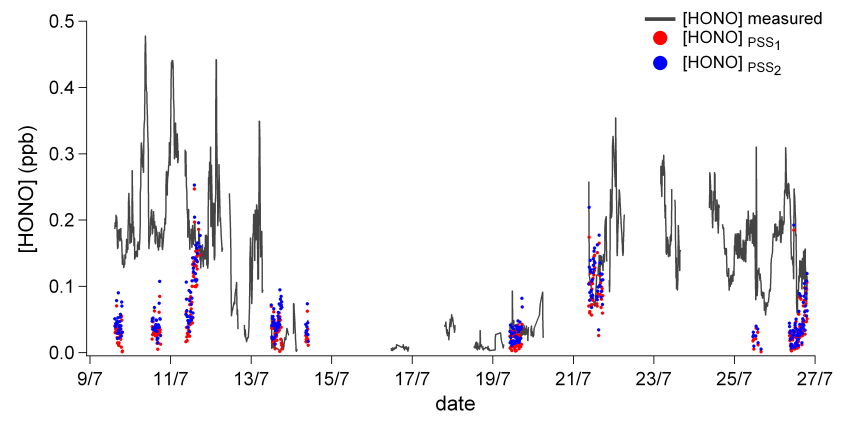

Fig. 5. Observed HONO mixing ratios (black lines) compared with PSS calculations (red circles for Eq. 1 and blue circles for Eq. 2) for the MEGAPOLI summer campaign. The calculations with the PSS approach are carried out only when all the parameters used in it are available.

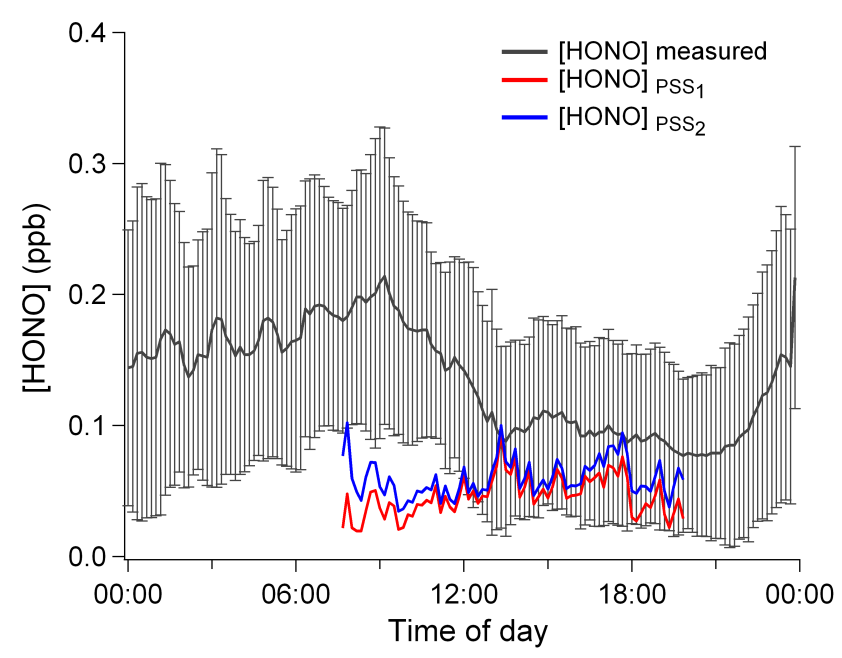

Fig. 6. Mean diurnal profiles of observed HONO mixing ratios (black lines) and HONO mixing ratios calculated using PSS calculation (red line for Eq. 1 and blue line for Eq. 2) for the MEGAPOLI summer campaign. Error bars correspond to standard deviation for day to day variability of measurements (local time).

\subsection{Comparison between PSS and measurements of HONO concentrations}

\subsubsection{The MEGAPOLI summer campaign}

To study the chemistry of HONO in the suburban environment of Palaiseau, measured HONO concentrations have been compared to calculated HONO concentrations determined from the PSS calculations (Eqs. 1 and 2). These comparisons are shown in Fig. 5 for the whole campaign and in Fig. 6 for diurnal profiles.

The comparison shows a relatively good agreement between measurements and calculations for some days, such as the 13, 19 and 21 July. Nevertheless, calculated HONO concentrations underestimate measured concentrations for the other days of the campaign. This is the case, in particular, on 


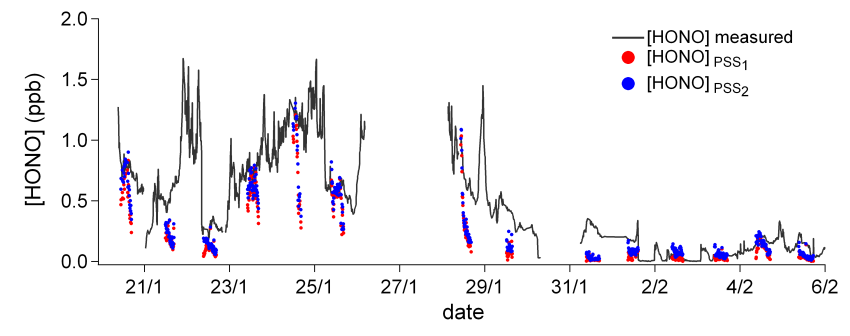

Fig. 7. Observed HONO mixing ratios (black lines) compared with PSS calculations (red circles for Eq. 1 and blue circles for Eq. 2) for the MEGAPOLI winter campaign. The calculations with the PSS approach are carried out only when all the parameters used in it are available.

the $9,10,11,25$ and 26 July. These underestimations are observed when high HONO mixing ratios (> $100 \mathrm{ppt}$ ) are measured (see Fig. 5). Note that we noticed that heterogeneous HONO sources on aerosol and ground surfaces and direct emission of HONO led only to a slight increase of calculated HONO concentrations. This slight increase cannot, by far, reconcile calculations and measurements and indicates that these processes have a low impact on the HONO budget.

This suggests the existence of an unaccounted additional HONO source, required to reconcile calculated and observed HONO concentrations. This statement seems robust even if the parameterizations used to take into account other processes than the homogeneous formation contain uncertainties (see Sect. 3).

\subsubsection{The MEGAPOLI winter campaign}

The comparison between measured and calculated HONO concentrations is shown in Fig. 7 for the whole winter campaign and in Fig. 8 for diurnal profiles.

As for the summer campaign, the calculated HONO concentrations underestimate the measurements in general, although a good agreement is found on some days, such as the 25 January and the 2, 3, 4 February. Agreement between calculations and measurements is generally found when measured HONO mixing ratios are low (some tens of ppt), but a good agreement is also found when higher HONO mixing ratios are observed (500-600 ppt), on the 25 January for instance.

This general underestimation of the calculations compared to the measurements is also illustrated by the comparison between the diurnal profiles. Furthermore, the profiles of both calculated HONO concentrations ([HONO $]_{\text {PSS1 }}$ and $\left.[\mathrm{HONO}]_{\mathrm{PSS} 2}\right)$ are quite similar, suggesting that HONO direct emissions and considered HONO heterogeneous sources only slightly contribute to HONO formation. In the same way as for the MEGAPOLI summer campaign, this general underestimation of the calculations also highlights the fact that the considered HONO formation processes are not sufficient

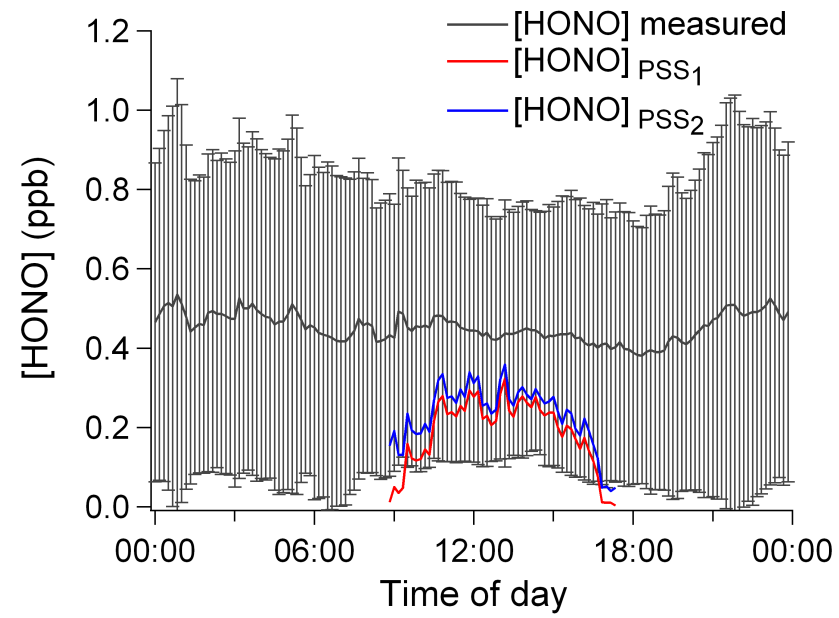

Fig. 8. Mean diurnal profiles of observed [HONO] mixing ratios (black line) and HONO mixing ratios calculated using PSS (red line for Eq. 1 and blue line for Eq. 2) for the MEGAPOLI winter campaign. Error bars correspond to standard deviation for day-to-day variability of measurements (local time).

to explain the observed daytime HONO levels during this campaign.

\subsection{Daytime missing HONO source}

The underestimations of calculated HONO concentrations found for both campaigns indicate that either HONO sources are underestimated or losses are overestimated. However, HONO losses are well established and are largely dominated by its photolysis during daytime. The underestimation of HONO concentrations is, therefore expected to come from one or several sources that are missing in the calculation.

It is thus necessary to include a HONO source term $\left(S_{\text {unknown }}\right)$ in Eq. (2) to account for these missing sources:

$[\mathrm{HONO}]=$

$\frac{k_{\mathrm{OH}+\mathrm{NO}}[\mathrm{OH}][\mathrm{NO}]+0.03\left[\mathrm{NO}_{2}\right] \frac{v_{\mathrm{NO}}}{h}+\frac{v_{a} c S}{4}\left[\mathrm{NO}_{2}\right]+\frac{0.008 \cdot E_{\mathrm{NOX}}}{h}+S_{\text {unknown }}}{k_{\mathrm{OH}+\mathrm{HONO}}[\mathrm{OH}]+J_{\mathrm{HONO}}+\frac{v_{\mathrm{HONO}}}{h}}$

This additional source term ( $S_{\text {unknown }}$ (Eq. 3 ) can thus be calculated using the following equation:

$$
\begin{aligned}
& S_{\text {unknown }}= \\
& \quad\left([\mathrm{HONO}]_{\text {measured }}-[\mathrm{HONO}]_{\mathrm{PSS} 2}\right) \cdot\left(k_{\mathrm{HONO}+\mathrm{OH}}[\mathrm{OH}]\right. \\
& \left.\quad+J_{\text {HONO }}+\frac{v_{\mathrm{HONO}}}{h}\right)
\end{aligned}
$$

$[\mathrm{HONO}]_{\mathrm{PSS} 2}$ in Eq. (4) represents HONO concentrations calculated using Eq. (2). This calculation has been established to estimate the additional HONO source term needed to reconcile observed and calculated HONO levels during the MEGAPOLI summer and winter campaigns. 


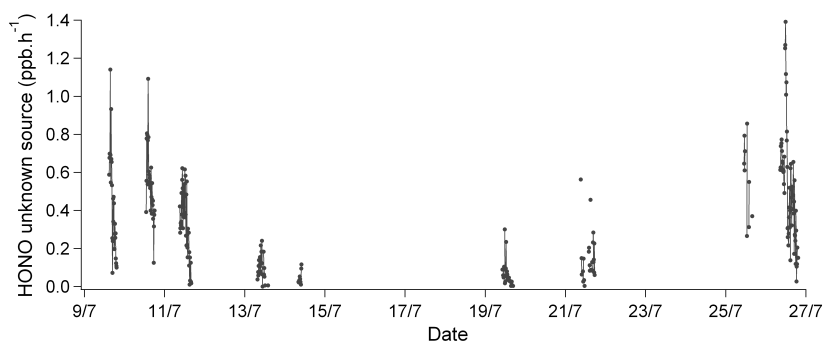

Fig. 9. Evolution of the calculated unknown HONO source in $\mathrm{ppbh}^{-1}$ (Eq. 4) during the MEGAPOLI summer campaign.

\subsubsection{The MEGAPOLI summer campaign}

The evolution of the missing HONO source during the MEGAPOLI summer campaign is shown in Fig. 9. The maxima at noon of this source range from 0.3 to $1.4 \mathrm{ppbh}^{-1}$. The diurnal profile of this missing HONO source is shown in Fig. 10. This unknown source presents a bell-shaped profile with an averaged maximum around noon of approximately $0.7 \mathrm{ppbh}^{-1}$. This is comparable to another study performed in a suburban environment near Jülich (Germany) during the ECHO campaign, where Kleffmann et al. (2005) found a missing HONO source with a maximum of approximately $0.5 \mathrm{ppbh}^{-1}$. It is also comparable to the additional HONO source found by Li et al. (2012) in the Pearl river delta at a site located $60 \mathrm{~km}$ north of Guangzhou, with an averaged daytime unknown HONO source of $0.77 \mathrm{ppb} \mathrm{h}^{-1}$. However, this source seems to be much higher than the one found by Zhou et al. (2002) in a rural environment of New York State (USA) with a maximum of approximately $0.22 \mathrm{ppbh}^{-1}$; and much lower than the one found by Elshorbany et al. (2009) in the urban city centre of Santiago (Chile) with a maximum of approximately $1.7 \mathrm{ppbh}^{-1}$. A comparison of these different additional HONO daytime sources is shown in Table 2. The additional HONO source seems, therefore, to be dependent on the encountered environmental conditions.

The calculated missing HONO source represents the main source of HONO during daytime hours and accounts for approximately 50 to $60 \%$ of the HONO production at noon, which is slightly higher than the production from the homogeneous reaction of $\mathrm{OH}$ with $\mathrm{NO}$ (see Fig. S1.1).

In order to identify the processes responsible for the unknown HONO source, correlations of this additional HONO source with various parameters were investigated. The selection of parameters was driven by processes already identified in the literature as HONO source:

- $\mathrm{NO}_{2}$ dismutation on wet surfaces (Reaction R3) (Finlayson-Pitts et al., 2003).

- Heterogeneous reduction of $\mathrm{NO}_{2}$ on soot surfaces (Reaction R4) (Ammann et al., 1998)

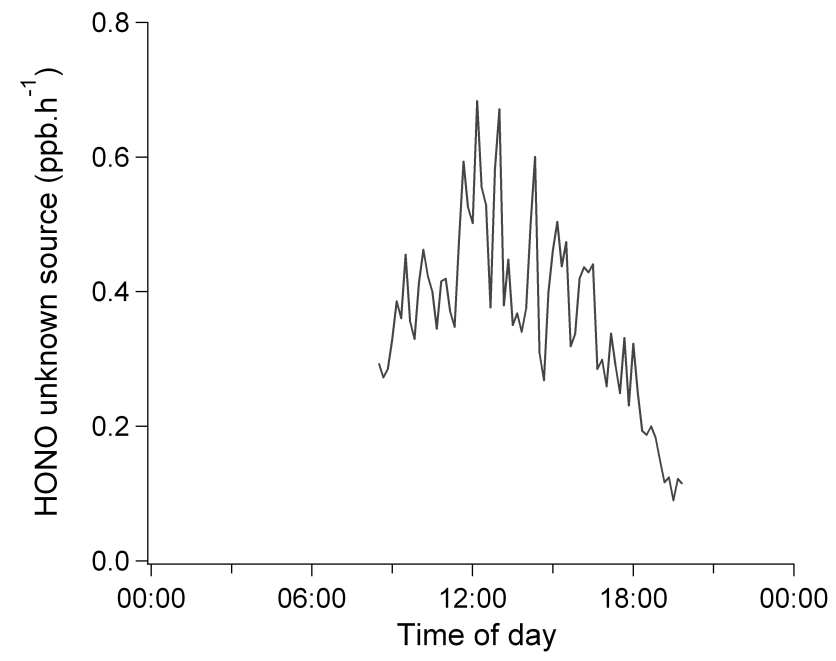

Fig. 10. Mean diurnal profile of the unknown HONO source calculated using Eq. (3), during MEGAPOLI summer campaign at SIRTA observatory (local time).

- Heterogeneous reactions between $\mathrm{NO}$ and $\mathrm{NO}_{2}$ or between $\mathrm{NO}$ and $\mathrm{HNO}_{3}$ (Calvert et al., 1994; Saliba et al., 2000).

- Heterogeneous reduction of $\mathrm{NO}_{2}$ on organic surfaces, such as humic acids (Stemmler et al., 2006) or aromatics (George et al., 2005).

The measured parameters or products of measured parameters confronted with the calculated unknown HONO source are: $\left[\mathrm{NO}_{2}\right]$, [NO], and $[\mathrm{NO}] \times\left[\mathrm{NO}_{2}\right]$. In addition, black carbon aerosol concentrations (BC) and $\mathrm{BC} \times\left[\mathrm{NO}_{2}\right]$ have also been compared with the calculated missing HONO source. The correlation plots obtained are presented in the Supplement (Fig. S2.1). These analyses do not show any clear relationship between the calculated unknown HONO source and the different parameters chosen. This seems to exclude the processes mentioned earlier as the major HONO additional source during the MEGAPOLI summer campaign at the SIRTA observatory. However, these processes can occur but probably with a low contribution. Moreover, processes such as reduction of $\mathrm{NO}_{2}$ on soot and on organic surfaces or dismutation of $\mathrm{NO}_{2}$ on wet surfaces are already taken into account in the calculation of PSS HONO concentrations (see Eq. 2).

Correlations between the calculated unknown HONO source and measured $J\left(\mathrm{NO}_{2}\right)$ and the product between measured $J\left(\mathrm{NO}_{2}\right)$ and soil moisture (measured $5 \mathrm{~cm}$ below ground) are presented in Fig. 11. On the contrary of graphs presented in the Supplement (see Fig S2.1), the graphs in Fig. 11 present a clear relationship between the calculated unknown $\mathrm{HONO}$ source and $\mathrm{NO}_{2}$ photolysis frequencies and between this source and the product of $J\left(\mathrm{NO}_{2}\right)$ and soil moisture. Indeed, the missing source seems growing with 

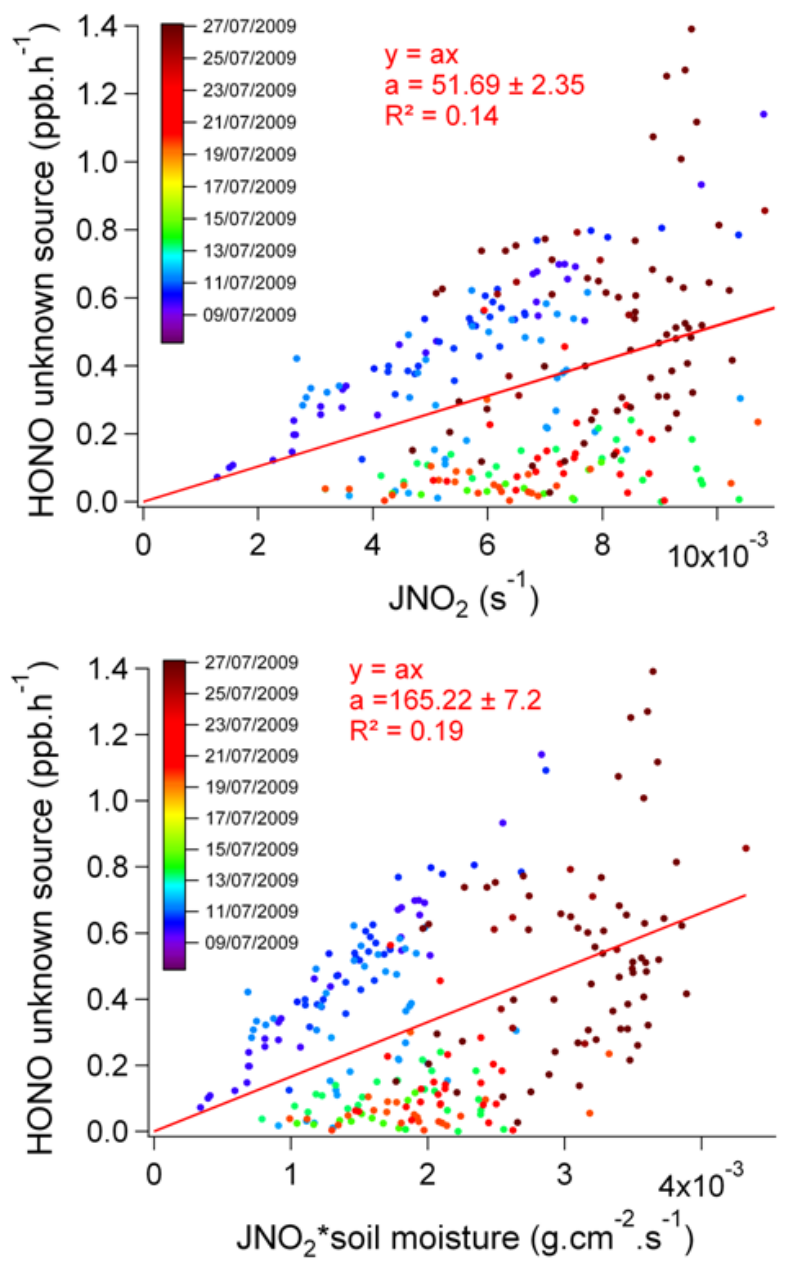

Fig. 11. Correlations between the unknown HONO source and measured $J\left(\mathrm{NO}_{2}\right)$ and the product between measured $J\left(\mathrm{NO}_{2}\right)$ and soil moisture measured at $5 \mathrm{~cm}$ below ground surface, during the MEGAPOLI summer campaign at SIRTA observatory. The dots of both correlations have been coloured as a function of the date.

increasing $J\left(\mathrm{NO}_{2}\right)$ and increase of the product of $J\left(\mathrm{NO}_{2}\right)$ and soil moisture, although the correlation coefficients of both graphs are quite low ( 0.14 and 0.19 respectively). Moreover, the correlation is slightly improved when we multiply soil moisture to $J\left(\mathrm{NO}_{2}\right)$ instead of considering just $J\left(\mathrm{NO}_{2}\right)$ alone. These correlations tend to indicate that the unknown HONO source observed during the MEGAPOLI summer campaign might be photolytic and heterogeneous occurring on the ground rather than on aerosols. On the contrary, no clear relationship is found for the correlation plot between the missing source and the term $J\left(\mathrm{NO}_{2}\right) \times\left[\mathrm{NO}_{2}\right]$ (see Supplement, Fig. S4.1). This lack of correlation between this two terms strengthen the feeling that gaseous $\mathrm{NO}_{2}$ does not take a part in the missing HONO formation processes observed during this campaign, in contradiction with suggestion of Sörgel et al. (2011a).
However, it seems that the poor correlation coefficient obtained for correlations shown in Fig. 11 requires an additional parameter to improve correlations with the unknown HONO source. Furthermore, when plotted as a function of the day of the campaign (colour coded points in Fig. 11), it seems that a better correlation exists for each day but with a high variability in the slope found for each day. The slopes and the correlation coefficients of the correlation plots between the unknown HONO source and $J\left(\mathrm{NO}_{2}\right)$ for each day of the campaign are listed in Table 3. Good correlations are found some days (for example 9 and 10 July) with high correlation coefficients. Nevertheless no correlation is found some other days. It is the case particularly for the days characterised by a good agreement between calculated and measured HONO concentrations (for example 11 and the 21 July). On these days a high error is found on the slopes and the correlation on these days should not be considered. This can be explained by the fact that the errors of the unknown source are expected to be far larger on days where calculated and measured HONO concentrations are close since it depends on the difference of both concentrations. In this sense, the slopes and correlation coefficient of the weighted regressions including the difference between measured and calculated HONO concentrations for each day of the campaign are presented in the supplements (see Supplement S7) showing improvement in correlation coefficient compared to simple regression.

The high variability in the slope found for each day indicates that the missing parameter should present a day to day variability but with lower variability during daytime hours of each day. Among the processes proposed in the literature which could meet these criteria, various potential HONO sources can be considered:

- The photolysis of nitric acid deposited on ground surfaces (Reactions R5-R7). Indeed, this reaction occurs heterogeneously on the ground and is photolytic. Furthermore, this reaction involves a water molecule and is thus dependent of the water content of the soil (Zhou et al., 2001, 2002). Moreover, this reaction is dependent of the reservoir of nitric acid or nitrates material available at the soil/atmosphere interface which is expected to present a day-to-day variability.

- HONO formation from nitrites contained in the soil and formed through biological processes (Reactions R8) (Su et al., 2011). This reaction depends on many parameters such as nitrite concentrations in soil, soil water content, soil temperature, soil $\mathrm{pH}$, etc. ...(Su et al., 2011), but is not photolytic. However, the calculated unknown HONO source is found not to correlate to soil temperature in our study (not shown).

Li et al. (2012) also proposed these two mechanisms to explain the additional HONO production observed during a field experiment conducted in the Pearl River delta. 
Table 2. Comparison of the level of the unknown HONO Source from various field campaigns conducted in various environments and different seasons.

\begin{tabular}{|c|c|c|c|}
\hline $\begin{array}{l}\text { Paper/ } \\
\text { Campaign }\end{array}$ & $\begin{array}{l}\text { Averaged daytime additional } \\
\text { HONO source }\left(\mathrm{ppb} \mathrm{h}^{-1}\right) / \\
\text { Range of daytime additional } \\
\text { HONO source }\left(\mathrm{ppb} \mathrm{h}^{-1}\right)\end{array}$ & Environment & Season \\
\hline This study & $0.7 /$ & Suburban (Paris region, France) & Summer \\
\hline MEGAPOLI summer campaign & $0.3-1.4$ & & \\
\hline Kleffmann et al. (2005) & $0.5 /$ & Suburban (near Jülich, Germany) & Summer \\
\hline ECHO & $\mathrm{nc}$ & & \\
\hline Li et al. (2012) & $0.77 /$ & Rural polluted (Pearl River Delta, China) & Summer \\
\hline PRIDE-PRD 2006 & nc & & \\
\hline Zhou et al. (2002) & $\begin{array}{l}0.22 / \\
\mathrm{nc}\end{array}$ & Rural (New York state, USA) & Summer \\
\hline Acker et al. (2006b) & $\begin{array}{l}0.43 / \\
0.3-0.6\end{array}$ & Rural mountain site (Hohenpeissenberg, Germany) & Summer \\
\hline Elshorbany et al. (2009) & $\begin{array}{l}1.7 / \\
\mathrm{nc}\end{array}$ & Urban (Santiago urban area, Chile) & Summer \\
\hline $\begin{array}{l}\text { Wong et al. (2012) } \\
\text { SHARP } 2009\end{array}$ & $\begin{array}{l}\mathrm{nc} / \\
0.7-1.3\end{array}$ & Urban (Houston urban area, USA) & Spring \\
\hline $\begin{array}{l}\text { This study } \\
\text { MEGAPOLI winter campaign }\end{array}$ & $\begin{array}{l}0.25 / \\
0.05-1.3\end{array}$ & Suburban (Paris region, France) & Winter \\
\hline $\begin{array}{l}\text { Sörgel et al. (2011a) } \\
\text { DOMINO }\end{array}$ & $\begin{array}{l}0.1 / \\
-0.7-1.8\end{array}$ & Forested site (South Spain) & Winter \\
\hline
\end{tabular}

In addition of these sources, one cannot exclude the photolysis of ortho-nitrophenols. Furthermore, Bejan et al. (2006) reported a production of HONO, at noon, through this process of approximately $100 \mathrm{ppth}^{-1}$ which cannot explain, by far, the whole unknown source observed in our study. Therefore, if this process cannot be disqualified during the MEGAPOLI summer campaign at SIRTA observatory, it cannot be the only additional process occurring during daytime hours.

The absence of measurements of atmospheric $\mathrm{HNO}_{3}$ concentrations and/or concentrations of $\mathrm{HNO}_{3}$ adsorbed on ground surfaces, nitrite concentrations in soil and atmospheric ortho-nitrophenol concentrations, does unfortunately not allow us to conclude on the contribution of these three processes to the HONO formation in the conditions of the MEGAPOLI summer campaign at SIRTA observatory.

\subsubsection{The MEGAPOLI winter campaign}

The evolution of the missing HONO source is shown in Fig. 12. During this campaign, the maxima at noon of this source range from 0.05 to $1.3 \mathrm{ppbh}^{-1}$. The diurnal profile of the missing HONO source for this campaign is shown in Fig. 13. This unknown HONO source presents a bell-shaped profile, similar to the one of the MEGAPOLI summer campaign. However, the level of this additional HONO source is approximately three times lower than the one of the summer campaign. Indeed, the averaged maximum for this unknown HONO daytime source is about $0.25 \mathrm{ppb} \mathrm{h}^{-1}$ while it was of

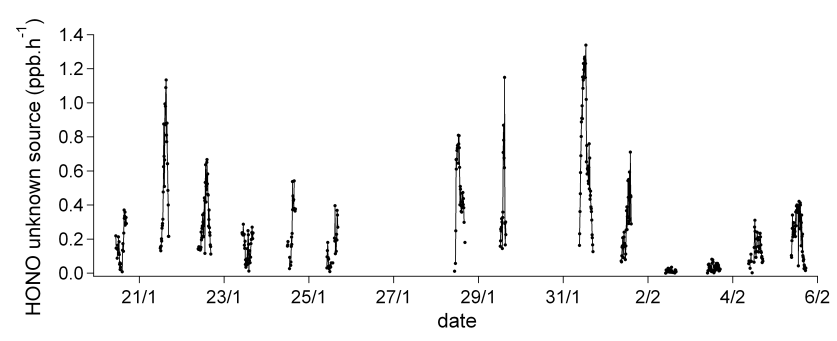

Fig. 12. Evolution of the calculated unknown HONO source in $\mathrm{ppbh}^{-1}$ (Eq. 4) during the MEGAPOLI winter campaign.

about $0.7 \mathrm{pb} \mathrm{h}^{-1}$ during the summer campaign. This indicates that this source may also be season dependent, strengthening the assumption of a photolytic source to explain this missing HONO formation. However, this source was higher than the one calculated by Sörgel et al. (2011a) in a forested area in winter, with an average daytime level of $0.1 \mathrm{ppb} \mathrm{h}^{-1}$ (see Table 2).

During this campaign, the unknown source represents also the main HONO source during daytime hours, approximately $50-60 \%$ of the averaged total HONO source at noon, which is slightly more than the homogeneous production from the $\mathrm{OH}+\mathrm{NO}$ reaction (see Fig. S1.2).

The same correlations plots, as for the summer source, have been built, again to identify possibly responsible processes for this source (see Sect. 4.3.1) and are presented in Supplement S2 (Fig. S2.2). As it was the case for the 
Table 3. Slopes, correlation coefficients and relative error of the slopes of the correlations between the calculated unknown $\mathrm{HONO}$ source and $J\left(\mathrm{NO}_{2}\right)$ for each days of the summer and winter campaigns

\begin{tabular}{rrrrr}
\hline campaign & Day & slopes & $\begin{array}{r}\text { correlation } \\
\text { coefficients }\left(R^{2}\right)\end{array}$ & $\begin{array}{r}\text { Error of the } \\
\text { slopes }(\%)\end{array}$ \\
\hline \multirow{6}{*}{ summer } & & & 0.94 & 2.4 \\
& $13 / 07$ & 91.1 & 0.82 & 2.6 \\
& $11 / 07$ & 89.2 & -0.06 & 8.9 \\
& $19 / 07$ & 18.1 & 0.32 & 8.3 \\
& $21 / 07$ & 19.4 & 0.24 & 14.7 \\
& $25 / 07$ & 74.8 & 0.04 & 14.7 \\
& $26 / 07$ & 64.0 & 0.26 & 10.6 \\
& $20 / 01$ & 201.4 & 0.10 & 6.7 \\
\hline \multirow{6}{*}{ winter } & $21 / 01$ & 246.3 & -0.05 & 9.5 \\
& $22 / 01$ & 115.7 & 0.85 & 4.0 \\
& $23 / 01$ & 104.6 & 0.58 & 5.3 \\
& $24 / 01$ & 352.3 & -1.09 & 12.9 \\
& $25 / 01$ & 58.1 & 0.35 & 9.5 \\
& $28 / 01$ & 283.0 & -0.41 & 21.7 \\
& $29 / 01$ & 247.4 & 0.90 & 2.4 \\
& $31 / 01$ & 205.6 & 0.98 & 1.5 \\
& $01 / 02$ & 80.2 & 0.97 & 1.4 \\
& $02 / 02$ & 11.4 & 0.68 & 5.3 \\
& $03 / 02$ & 17.5 & -0.03 & 14.9 \\
& $04 / 02$ & 51.8 & 0.53 & 6.9 \\
& $05 / 02$ & 68.9 & 0.55 & 5.4 \\
& & & 0.63 & 4.6 \\
\hline \multirow{6}{*}{} & & &
\end{tabular}

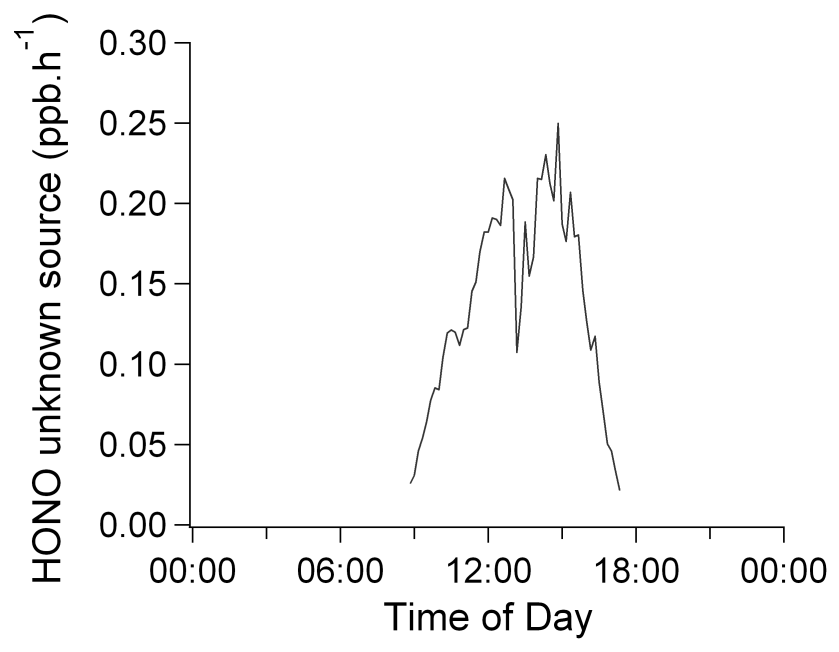

Fig. 13. Mean diurnal profile of the unknown HONO source calculated using Eq. (3), during the MEGAPOLI winter campaign at SIRTA observatory (local time).

MEGAPOLI summer campaign, these scatter plots do not show any clear relationship between the calculated HONO source and these parameters, excluding again processes men- tioned in Sect. 4.3.1 as major additional HONO source during the MEGAPOLI winter campaign.

Correlation plots between the calculated HONO unknown source and measured $J\left(\mathrm{NO}_{2}\right)$ and the product between measured $J\left(\mathrm{NO}_{2}\right)$ and soil moisture are presented in Fig. 14. Fair correlations, even better than for summer, are found between the additional HONO source and the two parameters with correlation coefficients of 0.39 for both correlations. Furthermore, on the whole, good correlation coefficients are found for each single day (see Table 3), except for the days when calculated HONO concentrations are in agreement with the measurements (see Supplement S7). However, no improvement is observed when we consider the product between $J\left(\mathrm{NO}_{2}\right)$ and soil moisture instead of $J\left(\mathrm{NO}_{2}\right)$ alone. This could be explained by low variability in the soil moisture data (see Fig. 4). Furthermore, one could expect multiple water layers over the surface in winter, diminishing HONO production efficiency (Saliba et al., 2001). However, this does not necessarily mean that the processes responsible for the unknown source observed during this campaign do not occur at ground.

In any case, the source observed during this campaign seems to be at least a photolytic source as during the MEGAPOLI summer campaign. This could explain the lower level of this source (approximately three times lower in average) since photolysis frequencies are far lower during the winter campaign than during the summer campaign (approximately three times lower). However, this could not explain the difference observed in the slope between the summer and the winter. Indeed, a factor of two approximately exists between the slopes of the correlations between the summer and the winter. This difference could be explained by a parameter not taken into account in the correlations and involved in the missing HONO source which would present a seasonal variation.

Therefore, the same processes than that proposed to explain the additional summer HONO source might be responsible for the winter unknown HONO source, i.e. photolysis of nitric acid deposited on ground surface, HONO formation from nitrites contained in the soil and photolysis of orthonitrophenols, although we cannot conclude on the exact contribution of these three processes to the additional HONO formation during this campaign.

\section{Conclusions}

HONO concentrations have been measured during the MEGAPOLI summer and winter campaigns at SIRTA observatory, in the Paris suburban area, using an instrument developed at the laboratory (NitroMAC). HONO levels measured during the MEGAPOLI summer campaign were variables reaching up to $500 \mathrm{ppt}$ during morning hours and mixing ratios comprised between a few tens of ppt and $200 \mathrm{ppt}$ during daytime. Thus, measured HONO mixing ratios were quite 


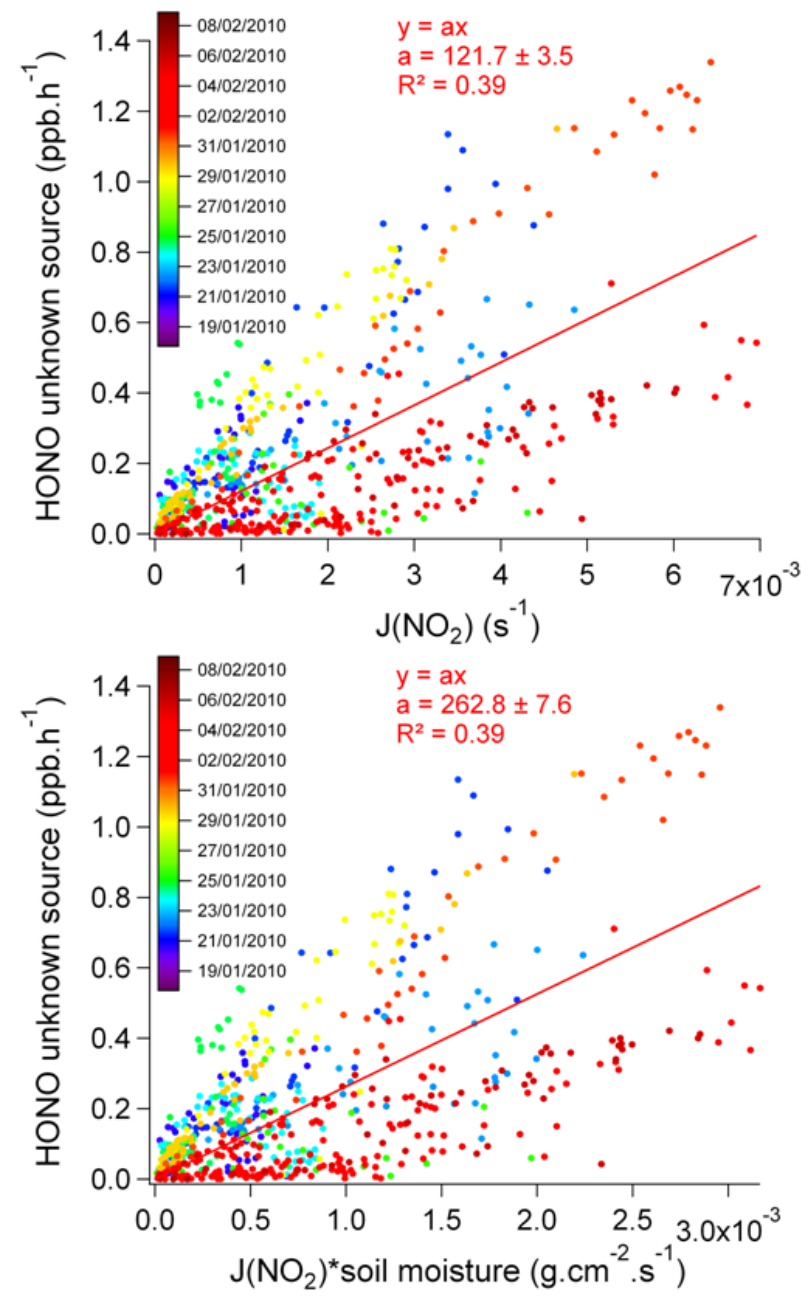

Fig. 14. Correlations between the unknown HONO source and measured $J\left(\mathrm{NO}_{2}\right)$ and the product between measured $J\left(\mathrm{NO}_{2}\right)$ and soil moisture measured at $5 \mathrm{~cm}$ below ground surface, during the MEGAPOLI winter campaign at SIRTA observatory. The dots of both correlations have been coloured as a function of the date.

high during this campaign, in average $(\sim 100 \mathrm{ppt})$, during daytime hours. Furthermore, HONO photolysis represents the main radical source during this campaign (Michoud et al., 2012). During the MEGAPOLI winter campaign, higher HONO levels were encountered with averaged daytime values around 400-500 ppt and a maximum values reaching up to $1.7 \mathrm{ppb}$ on some days.

A comparison has been conducted between daytime HONO concentrations measured and calculated ones using a PSS approximation. This comparison led, most of the time, to an underestimation of calculations compared to measurements, except for a few days for both campaigns. Therefore, homogeneous formation as well as emission and $\mathrm{NO}_{2}$ conversion on aerosol and ground fail, most of the time, to reproduce HONO daytime concentrations observed during the campaigns. This indicates the existence of one or several additional processes responsible for HONO formation during daytime hours for both campaigns. A missing daytime HONO source has, thus, been calculated from the difference between measured and calculated HONO concentrations for both campaigns.

This diurnal variation of the unknown HONO source presents a bell-shaped profile with a maximum around noon of approximately $0.7 \mathrm{ppbh}^{-1}$ and $0.25 \mathrm{ppbh}^{-1}$ for the summer and the winter campaign respectively.

This missing source has then been confronted to various parameters, which allows us to exclude some processes proposed in the literature to explain this source. It appeared that this source is correlated with $J\left(\mathrm{NO}_{2}\right)$ and with the product between $J\left(\mathrm{NO}_{2}\right)$ and soil moisture in both cases. This could therefore indicate that this missing source would be photolytic and maybe heterogeneous occurring on ground surface and depending on parameters that is changing from day to day. Some processes proposed in the literature have been identified as potential candidates to explain this additional HONO source observed during the MEGAPOLI summer and winter campaigns. This is the case of the photolysis of nitric acid or nitrates adsorbed on ground surface, of soil nitrites conversion into HONO and of the photolysis of ortho-nitrophenols. Nevertheless, in the absence of measurements of adsorbed nitrates and/or nitric acid concentrations, soil nitrite concentrations and/or gaseous ortho-nitrophenols concentrations, it is difficult to conclude on the exact contribution of these processes to the additional HONO formation during the MEGAPOLI campaigns. Thus, other unknown sources for HONO formation cannot be excluded, as long as they are correlated with photolysis rates and possibly soil moisture. Finally, the validation of the processes identified as potential candidates to explain the additional HONO source in this study requires new field experiments dedicated to HONO budget during which soil biological, chemical and physical properties would be measured simultaneously with atmospheric chemical and physical properties.

\section{Supplementary material related to this article is available online at http://www.atmos-chem-phys.net/14/ 2805/2014/acp-14-2805-2014-supplement.pdf.}

Acknowledgements. The research leading to these results has received funding from the European Union's Seventh Framework Programme FP/2007-2011 under grant agreement no. 212520. The authors acknowledge the ANR through the MEGAPOLI PARIS and INSU/ LEFE through the MEGAPOLI France project for their financial support. Moreover, the research leading to these results has been carried out in the framework of a thesis supported by CNRS grant. The authors also want to thank Eurochamp-2 (EU-FP7 grant agreement no. 228335) for supporting intercalibration exercises, in particular through the FIONA experiment dedicated to intercomparison of HONO measurements. The authors acknowledge Birger Bohn, Forschungszentrum Jülich, 
Germany, for the calibration of the $J\left(\mathrm{NO}_{2}\right)$ filter radiometer. Acknowledgements are extended to TNO for providing $\mathrm{NO}_{\mathrm{x}}$ emission inventory in the framework of MEGAPOLI project and to N. Bousserhine for helpful discussion about soil biological activity. Finally, the authors also thank J. Sciare and J. B. Nicolas for the BC.

Edited by: C. Reeves

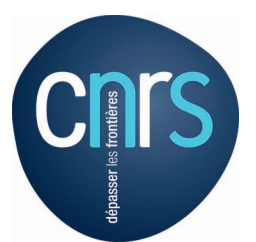

The publication of this article is financed by CNRS-INSU.

\section{References}

Acker, K., Febo, A., Trick, S., Perrino, C., Bruno, P., Wiesen, P., Möller, D., Wieprecht, W., Auel, R., Giusto, M., Geyer, A., Platt, U., and Allegrini, I.: Nitrous acid in the urban area of rome, Atmos. Environ., 40, 3123-3133, doi:10.1016/j.atmosenv.2006.01.028, 2006a.

Acker, K., Möller, D., Wieprecht, W., Meixner, F. X., Bohn, B., Gilge, S., Plass-Dülmer, C., and Berresheim, H.: Strong daytime production of $\mathrm{OH}$ from $\mathrm{HNO}_{2}$ at a rural mountain site, Geophys. Res. Lett., 33, L02809, doi:10.1029/2005GL024643, 2006b.

Afif, C.: L'acide nitreux atmosphérique: Implications dans la chimie en milieu urbain, Université Paris XII- Val de Marne, Université Saint-Joseph de Beyrouth, Créteil, Beyrouth, 2008.

Afif, C., Jambert, C., Colomb, A., Eyglunent, G., Borbon, A., Daële, V., Doussin, J. F., and Perros, P. E.: NitroMAC: an instrument for the measurement of HONO. Intercomparison with LOPAP, Water Air Soil Poll., in preparation, 2014.

Ait-Helal, W., Borbon, A., Sauvage, S., de Gouw, J. A., Colomb, A., Gros, V., Freutel, F., Crippa, M., Afif, C., Baltensperger, U., Beekmann, M., Doussin, J.-F., Durand-Jolibois, R., Fronval, I., Grand, N., Leonardis, T., Lopez, M., Michoud, V., Miet, K., Perrier, S., Prévôt, A. S. H., Schneider, J., Siour, G., Zapf, P., and Locoge, N.: Volatile and intermediate-volatility organic compounds in sub-urban Paris: variability, origin and importance for SOA formation, Atmos. Chem. Phys. Discuss., 14, 4841-4904, doi:10.5194/acpd-14-4841-2014, 2014.

Alicke, B., Geyer, A., Hofzumahaus, A., Holland, F., Konrad, S., Pätz, H. W., Schäfer, J., Stutz, J., Volz-Thomas, A., and Platt, U.: $\mathrm{OH}$ formation by $\mathrm{HONO}$ photolysis during the BERLIOZ experiment, J. Geophys. Res., 108, 8247, doi:10.1029/2001jd000579, 2003

Amedro, D., Parker, A. E., Schoemaecker, C., and Fittschen, C.: Direct observation of $\mathrm{OH}$ radicals after $565 \mathrm{~nm}$ multi-photon excitation of $\mathrm{NO}_{2}$ in the presence of $\mathrm{H}_{2} \mathrm{O}$, Chem. Phys. Lett., 513, 12-16, doi:10.1016/j.cplett.2011.07.062, 2011.

Ammann, M., Kalberer, M., Jost, D. T., Tobler, L., Rössler, E., Piguet, D., Gäggeler, H. W., and Baltensperger, U.: Heterogeneous production of nitrous acid on soot in polluted air masses, Nature, 395, 157-160, doi:10.1038/25965, 1998.

Atkinson, R., Baulch, D. L., Cox, R. A., Crowley, J. N., Hampson, R. F., Hynes, R. G., Jenkin, M. E., Rossi, M. J., and Troe, J.: Evaluated kinetic and photochemical data for atmospheric chem- istry: Volume $\mathrm{I}$ - gas phase reactions of $\mathrm{O}_{\mathrm{x}}, \mathrm{HO}_{\mathrm{x}}, \mathrm{NO}_{\mathrm{x}}$ and $\mathrm{SO}_{\mathrm{x}}$ species, Atmos. Chem. Phys., 4, 1461-1738, doi:10.5194/acp-41461-2004, 2004.

Aumont, B., Madronich, S., Ammann, M., Kalberer, M., Baltensperger, U., Hauglustaine, D., and Brocheton, F.: On the $\mathrm{NO}_{2}$ + soot reaction in the atmosphere, J. Geophys. Res., 104, 17291736, doi:10.1029/1998jd100023, 1999.

Bejan, I., Abd El Aal, Y., Barnes, I., Benter, T., Bohn, B., Wiesen, P., and Kleffmann, J.: The photolysis of ortho-nitrophenols: a new gas phase source of HONO, Phys. Chem. Chem. Phys., 8, 2028 2035, doi:10.1039/b516590c, 2006.

Berresheim, H., Elste, T., Plass-Dülmer, C., Eisele, F. L., and Tanner, D. J.: Chemical ionization mass spectrometer for long-term measurements of atmospheric $\mathrm{OH}$ and $\mathrm{H}_{2} \mathrm{SO}_{4}$, Int. J. Mass Spectrom., 202, 91-109, 2000.

Bloss, C., Wagner, V., Jenkin, M. E., Volkamer, R., Bloss, W. J., Lee, J. D., Heard, D. E., Wirtz, K., Martin-Reviejo, M., Rea, G., Wenger, J. C., and Pilling, M. J.: Development of a detailed chemical mechanism (MCMv3.1) for the atmospheric oxidation of aromatic hydrocarbons, Atmos. Chem. Phys., 5, 641-664, doi:10.5194/acp-5-641-2005, 2005.

Calvert, J. G., Yarwood, G., and Dunker, A. M.: An evaluation of the mechanism of Nitrous Acid formation in the urban atmosphere, Res. Chem. Intermediat., 20, 463-502, doi:10.1163/156856794x00423, 1994.

Crippa, M., DeCarlo, P. F., Slowik, J. G., Mohr, C., Heringa, M. F., Chirico, R., Poulain, L., Freutel, F., Sciare, J., Cozic, J., Di Marco, C. F., Elsasser, M., Nicolas, J. B., Marchand, N., Abidi, E., Wiedensohler, A., Drewnick, F., Schneider, J., Borrmann, S., Nemitz, E., Zimmermann, R., Jaffrezo, J.-L., Prévôt, A. S. H., and Baltensperger, U.: Wintertime aerosol chemical composition and source apportionment of the organic fraction in the metropolitan area of Paris, Atmos. Chem. Phys., 13, 961-981, doi:10.5194/acp-13-961-2013, 2013.

Denier van der Gon, H., Visschedijk, A., van der Brugh, H., Droge, R., and Kuenen, J.: A base year (2005) megapoli uropean gridded emission inventory (1st version), MEGAPOLI Scientific Report 09-02, Deliverable 1.2, 2009.

Dusanter, S., Vimal, D., Stevens, P. S., Volkamer, R., Molina, L. T., Baker, A., Meinardi, S., Blake, D., Sheehy, P., Merten, A., Zhang, R., Zheng, J., Fortner, E. C., Junkermann, W., Dubey, M., Rahn, T., Eichinger, B., Lewandowski, P., Prueger, J., and Holder, $\mathrm{H}$.: Measurements of $\mathrm{OH}$ and $\mathrm{HO}_{2}$ concentrations during the MCMA-2006 field campaign - Part 2: Model comparison and radical budget, Atmos. Chem. Phys., 9, 6655-6675, doi:10.5194/acp-9-6655-2009, 2009.

Eisele, F. L. and Tanner, D. J.: Ion-assisted tropospheric OH measurement, J. Geophys. Res., 96, 9295-9308, doi:10.1029/91jd00198, 1991.

Elshorbany, Y. F., Kurtenbach, R., Wiesen, P., Lissi, E., Rubio, M., Villena, G., Gramsch, E., Rickard, A. R., Pilling, M. J., and Kleffmann, J.: Oxidation capacity of the city air of Santiago, Chile, Atmos. Chem. Phys., 9, 2257-2273, doi:10.5194/acp-92257-2009, 2009.

Finlayson-Pitts, B. J. and Pitts, J. N.: Chemistry of the upper and lower atmosphere, edited by: Academic Press, San Diego, 2000.

Finlayson-Pitts, B. J., Wingen, L. M., Sumner, A. L., Syomin, D., and Ramazan, K. A.: The heterogeneous hydrolysis of $\mathrm{NO}_{2}$ in laboratory systems and in outdoor and indoor atmospheres: An 
integrated mechanism, Phys. Chem. Chem. Phys., 5, 223-242, doi:10.1039/b208564j, 2003.

Freutel, F., Schneider, J., Drewnick, F., von der Weiden-Reinmüller, S.-L., Crippa, M., Prévôt, A. S. H., Baltensperger, U., Poulain, L., Wiedensohler, A., Sciare, J., Sarda-Estève, R., Burkhart, J. F., Eckhardt, S., Stohl, A., Gros, V., Colomb, A., Michoud, V., Doussin, J. F., Borbon, A., Haeffelin, M., Morille, Y., Beekmann, M., and Borrmann, S.: Aerosol particle measurements at three stationary sites in the megacity of Paris during summer 2009: meteorology and air mass origin dominate aerosol particle composition and size distribution, Atmos. Chem. Phys., 13, 933-959, doi:10.5194/acp-13-933-2013, 2013.

George, C., Strekowski, R. S., Kleffmann, J., Stemmler, K., and Ammann, M.: Photoenhanced uptake of gaseous $\mathrm{NO}_{2}$ on solidorganic compounds: a photochemical source of HONO?, Faraday Discuss., 130, 195-210, doi:10.1039/b417888m, 2005.

Haeffelin, M., Barthès, L., Bock, O., Boitel, C., Bony, S., Bouniol, D., Chepfer, H., Chiriaco, M., Cuesta, J., Delanoë, J., Drobinski, P., Dufresne, J.-L., Flamant, C., Grall, M., Hodzic, A., Hourdin, F., Lapouge, F., Lemaître, Y., Mathieu, A., Morille, Y., Naud, C., Noël, V., O'Hirok, W., Pelon, J., Pietras, C., Protat, A., Romand, B., Scialom, G., and Vautard, R.: SIRTA, a ground-based atmospheric observatory for cloud and aerosol research, Ann. Geophys., 23, 253-275, doi:10.5194/angeo-23-253-2005, 2005.

Haeffelin, M., Angelini, F., Morille, Y., Martucci, G., Frey, S., Gobbi, G. P., Lolli, S., O’Dowd, C. D., Sauvage, L., XuerefRemy, I., Wastine, B., and Feist, D. G.: Evaluation of MixingHeight Retrievals from Automatic Profiling Lidars and Ceilometers in View of Future Integrated Networks in Europe, Bound.Lay. Meteorol., 143, 49-75, doi:10.1007/s10546-011-9643-z, 2012.

Hasel, M., Kottmeier, C., Corsmeier, U., and Wieser, A.: Airborne measurements of turbulent trace gas fluxes and analysis of eddy structure in the convective boundary layer over complex terrain, Atmos. Res., 74, 381-402, doi:10.1016/j.atmosres.2004.06.010, 2005.

Häseler, R., Brauers, T., Holland, F., and Wahner, A.: Development and application of a new mobile LOPAP instrument for the measurement of HONO altitude profiles in the planetary boundary layer, Atmos. Meas. Tech. Discuss., 2, 2027-2054, doi:10.5194/amtd-2-2027-2009, 2009.

Huang, G., Zhou, X., Deng, G., Qiao, H., and Civerolo, K.: Measurements of atmospheric nitrous acid and nitric acid, Atmos. Environ., 36, 2225-2235, doi:10.1016/s1352-2310(02)00170-x, 2002.

Jenkin, M. E., Cox, R. A., and Williams, D. J.: Laboratory studies of the kinetics of formation of Nitrous Acid from the thermal reaction of nitrogen dioxide and water vapor, Atmos. Environ., 22, 487-498, doi:10.1016/0004-6981(88)90194-1, 1988.

Jenkin, M. E., Saunders, S. M., Wagner, V., and Pilling, M. J.: Protocol for the development of the Master Chemical Mechanism, MCM v3 (Part B): tropospheric degradation of aromatic volatile organic compounds, Atmos. Chem. Phys., 3, 181-193, doi:10.5194/acp-3-181-2003, 2003.

Kalberer, M., Ammann, M., Arens, F., Gäggeler, H. W., and Baltensperger, U.: Heterogeneous formation of nitrous acid (HONO) on soot aerosol particles, J. Geophys. Res., 104, 13825-13832, doi:10.1029/1999jd900141, 1999.
Kirchstetter, T. W., Harley, R. A., and Littlejohn, D.: Measurement of nitrous acid in motor vehicle exhaust, Environ. Sci. Technol., 30, 2843-2849, doi:10.1021/es960135y, 1996.

Kleffmann, J.: Daytime sources of nitrous acid (HONO) in the atmospheric boundary layer, Chem. Phys. Chem., 8, 1137-1144, 2007.

Kleffmann, J. and Wiesen, P.: Heterogeneous conversion of $\mathrm{NO}_{2}$ and $\mathrm{NO}$ on $\mathrm{HNO}_{3}$ treated soot surfaces: atmospheric implications, Atmos. Chem. Phys., 5, 77-83, doi:10.5194/acp-5-772005, 2005.

Kleffmann, J., Becker, K. H., and Wiesen, P.: Heterogeneous $\mathrm{NO}_{2}$ conversion processes on acid surfaces: Possible atmospheric implications, Atmos. Environ., 32, 2721-2729, doi:10.1016/s13522310(98)00065-x, 1998.

Kleffmann, J., Becker, K. H., Lackhoff, M., and Wiesen, P.: Heterogeneous conversion of $\mathrm{NO}_{2}$ on carbonaceous surfaces, Phys. Chem. Chem. Phys., 1, 5443-5450, 1999.

Kleffmann, J., Kurtenbach, R., Lörzer, J., Wiesen, P., Kalthoff, N., Vogel, B., and Vogel, H.: Measured and simulated vertical profiles of nitrous acid - Part I: Field measurements, Atmos. Environ., 37, 2949-2955, doi:10.1016/s1352-2310(03)00242-5, 2003.

Kleffmann, J., Benter, T., and Wiesen, P.: Heterogeneous reaction of nitric acid with nitric oxide on glass surfaces under simulated atmospheric conditions, J. Phys. Chem. A, 108, 5793-5799, doi:10.1021/jp040184u, 2004.

Kleffmann, J., Gavriloaiei, T., Hofzumahaus, A., Holland, F., Koppmann, R., Rupp, L., Schlosser, E., Siese, M., and Wahner, A.: Daytime formation of nitrous acid: A major source of $\mathrm{OH}$ radicals in a forest, Geophys. Res. Lett., 32, L05818,doi:10.1029/2005g1022524, 2005.

Kleffmann, J., Lörzer, J. C., Wiesen, P., Kern, C., Trick, S., Volkamer, R., Rodenas, M., and Wirtz, K.: Intercomparison of the DOAS and LOPAP techniques for the detection of nitrous acid (HONO), Atmos. Environ., 40, 3640-3652, doi:10.1016/j.atmosenv.2006.03.027, 2006.

Kukui, A., Ancellet, G., and Le Bras, G.: Chemical ionisation mass spectrometer for measurements of $\mathrm{OH}$ and Peroxy radical concentrations in moderately polluted atmospheres, J. Atmos. Chem., 61, 133-154, 2008.

Kurtenbach, R., Becker, K. H., Gomes, J. A. G., Kleffmann, J., Lörzer, J. C., Spittler, M., Wiesen, P., Ackermann, R., Geyer, A., and Platt, U.: Investigations of emissions and heterogeneous formation of HONO in a road traffic tunnel, Atmos. Environ., 35, 3385-3394, doi:10.1016/s1352-2310(01)00138-8, 2001.

Lammel, G. and Cape, J. N.: Nitrous acid and nitrite in the atmosphere, Chem. Soc. Rev., 25, 361-369, doi:10.1039/cs9962500361, 1996.

Levy, H.: Photochemistry of the lower troposphere, Planet. Space Sci., 20, 919-935, 1972.

Li, S., Matthews, J., and Sinha, A.: Atmospheric hydroxyl radical production from electronically excited $\mathrm{NO}_{2}$ and $\mathrm{H}_{2} \mathrm{O}$, Science, 319, 1657-1660, doi:10.1126/science.1151443, 2008.

Li, Y. Q., Schwab, J. J., and Demerjian, K. L.: Fast time response measurements of gaseous nitrous acid using a tunable diode laser absorption spectrometer: Hono emission source from vehicle exhausts, Geophys. Res. Lett., 35, L04803, doi:10.1029/2007g1031218, 2008. 
Li, X., Brauers, T., Häseler, R., Bohn, B., Fuchs, H., Hofzumahaus, A., Holland, F., Lou, S., Lu, K. D., Rohrer, F., Hu, M., Zeng, L. M., Zhang, Y. H., Garland, R. M., Su, H., Nowak, A., Wiedensohler, A., Takegawa, N., Shao, M., and Wahner, A.: Exploring the atmospheric chemistry of nitrous acid (HONO) at a rural site in Southern China, Atmos. Chem. Phys., 12, 1497-1513, doi:10.5194/acp-12-1497-2012, 2012.

Liao, W., Case, A. T., Mastromarino, J., Tan, D., and Dibb, J. E.: Observations of hono by laser-induced fluorescence at the South Pole during ANTCI 2003, Geophys. Res. Lett., 33, L09810, doi:10.1029/2005g1025470, 2006.

Michoud, V., Kukui, A., Camredon, M., Colomb, A., Borbon, A., Miet, K., Aumont, B., Beekmann, M., Durand-Jolibois, R., Perrier, S., Zapf, P., Siour, G., Ait-Helal, W., Locoge, N., Sauvage, S., Afif, C., Gros, V., Furger, M., Ancellet, G., and Doussin, J. F.: Radical budget analysis in a suburban European site during the MEGAPOLI summer field campaign, Atmos. Chem. Phys., 12, 11951-11974, doi:10.5194/acp-12-11951-2012, 2012.

Neftel, A., Blatter, A., Hesterberg, R., and Staffelbach, T.: Measurements of concentration gradients of $\mathrm{hno}_{2}$ and $\mathrm{hno}_{3}$ over a semi-natural ecosystem, Atmos. Environ., 30, 3017-3025, doi:10.1016/1352-2310(96)00011-8, 1996.

Park, S. S., Hong, S. B., Jung, Y. G., and Lee, J. H.: Measurements of $\mathrm{PM}_{10}$ aerosol and gas-phase nitrous acid during fall season in a semi-urban atmosphere, Atmos. Environ., 38, 293 304, doi:10.1016/j.atmosenv.2003.09.041, 2004

Pietras, C., Boitel, C., Dupont, J. C., Haeffelin, M., Lapouge, F., Morille, Y., Noel, V., and Romand, B.: SIRTA, a multisensor platform for clouds and aerosols characterisation in the atmosphere: infrastructure, objective and prospective - art. No. 67501A, in: Lidar Technologies, Techniques, and Measurements for Atmospheric Remote Sensing Iii, Proceedings of the Society of Photo-Optical Instrumentation Engineers (Spie), A7501A7501, 2007.

Platt, U., Alicke, B., Dubois, R., Geyer, A., Hofzumahaus, A., Holland, F., Martinez, M., Mihelcic, D., Klüpfer, T., Lohrmann, B., Pätz, W., Perner, D., Rohrer, F., Schäfer, J., and Stutz, J.: Free radicals and fast photochemistry during BERLIOZ, J. Atmos. Chem., 42, 359-394, doi:10.1023/a:1015707531660, 2002.

Ren, X., Harder, H., Martinez, M., Lesher, R. L., Oliger, A., Simpas, J. B., Brune, W. H., Schwab, J. J., Demerjian, K. L., He, Y., Zhou, $\mathrm{X}$., and $\mathrm{Gao}, \mathrm{H}$.: $\mathrm{OH}$ and $\mathrm{HO}_{2}$ chemistry in the urban atmosphere of New York City, Atmos. Environ., 37, 3639-3651, 2003.

Ren, X., Brune, W. H., Oliger, A., Metcalf, A. R., Simpas, J. B., Shirley, T., Schwab, J. J., Bai, C. H., Roychowdhury, U., Li, Y. Q., Cai, C. X., Demerjian, K. L., He, Y., Zhou, X.,

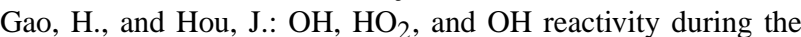
PMTACS-NY Whiteface Mountain 2002 campaign: Observations and model comparison, J. Geophys. Res., 111, D10S03, doi:10.1029/2005JD006126, 2006.

Saliba, N. A., Mochida, M., and Finlayson-Pitts, B. J.: Laboratory studies of sources of HONO in polluted urban atmospheres, Geophys. Res. Lett., 27, 3229-3232, doi:10.1029/2000gl011724, 2000.

Saliba, N. A., Yang, H., and Finlayson-Pitts, B. J.: Reaction of gaseous nitric oxide with nitric acid on silica surfaces in the presence of water at room temperature, J. Phys. Chem. A, 105, 10339-10346, doi:10.1021/jp012330r, 2001
Saunders, S. M., Jenkin, M. E., Derwent, R. G., and Pilling, M. J.: World Wide Web site of a Master Chemical Mechanism (MCM) for use in tropospheric chemistry models, Atmos. Environ., 31, 1249-1249, 1997.

Saunders, S. M., Jenkin, M. E., Derwent, R. G., and Pilling, M. J.: Protocol for the development of the Master Chemical Mechanism, MCM v3 (Part A): tropospheric degradation of nonaromatic volatile organic compounds, Atmos. Chem. Phys., 3, 161-180, 2003, http://www.atmos-chem-phys.net/3/161/2003/.

Seinfeld, J. H. and Pandis, S. N.: Atmospheric Chemistry and Physics, Wiley-Interscience, New York, 1998.

Sörgel, M., Regelin, E., Bozem, H., Diesch, J.-M., Drewnick, F., Fischer, H., Harder, H., Held, A., Hosaynali-Beygi, Z., Martinez, M., and Zetzsch, C.: Quantification of the unknown HONO daytime source and its relation to $\mathrm{NO}_{2}$, Atmos. Chem. Phys., 11, 10433-10447, doi:10.5194/acp-11-10433-2011, $2011 \mathrm{a}$.

Sörgel, M., Trebs, I., Serafimovich, A., Moravek, A., Held, A., and Zetzsch, C.: Simultaneous HONO measurements in and above a forest canopy: influence of turbulent exchange on mixing ratio differences, Atmos. Chem. Phys., 11, 841-855, doi:10.5194/acp11-841-2011, 2011b.

Stemmler, K., Ammann, M., Donders, C., Kleffmann, J., and George, C.: Photosensitized reduction of nitrogen dioxide on humic acid as a source of nitrous acid, Nature, 440, 195-198, doi:10.1038/nature04603, 2006.

Stockwell, W. R. and Calvert, J. G.: The Mechanism of $\mathrm{NO}_{3}$ and $\mathrm{HONO}$ formation in the nighttime chemistry of the urban atmosphere, J. Geophys. Res., 88, 6673-6682, doi:10.1029/JC088iC11p06673, 1983.

Stutz, J., Alicke, B., and Neftel, A.: Nitrous acid formation in the urban atmosphere: Gradient measurements of $\mathrm{NO}_{2}$ and HONO over grass in Milan, Italy, J. Geophys. Res., 107, 8192, doi:10.1029/2001jd000390, 2002.

Su, H., Cheng, Y., Shao, M., Gao, D. F., Yu, Z. Y., Zeng, L. M., Slanina, J., Zhang, Y. H., and Wiedensohler, A.: Nitrous acid (HONO) and its daytime sources at a rural site during the 2004 PRIDE-PRD experiment in China, J. Geophys. Res., 113, D14312, doi:10.1029/2007jd009060, 2008.

Su, H., Cheng, Y., Oswald, R., Behrendt, T., Trebs, I., Meixner, F. X., Andreae, M. O., Cheng, P., Zhang, Y., and Pöschl, U.: Soil Nitrite as a Source of Atmospheric HONO and OH Radicals, Science, 333, 1616-1618, doi:10.1126/science.1207687, 2011.

Tanner, D. J., Jefferson, A., and Eisele, F. L.: Selected ion chemical ionization mass spectrometric measurement of $\mathrm{OH}, \mathrm{J}$. Geophys. Res., 102, 6415-6425, 1997.

Tyndall, G. S., Orlando, J. J., and Calvert, J. G.: Upper limit for the rate coefficient for the reaction $\mathrm{ho}_{2}+\mathrm{no}_{2}$-]hono $+\mathrm{o}_{2}$, Environ Sci. Technol., 29, 202-206, doi:10.1021/es00001a026, 1995.

Veitel, H., Kromer, B., Mössner, M., and Platt, U.: New techniques for measurements of atmospheric vertical trace gas profiles using DOAS, Environ. Sci. Pollut. R., 9, 17-26, 2002.

Veres, P., Roberts, J. M., Burling, I. R., Warneke, C., de Gouw, J., and Yokelson, R. J.: Measurements of gas-phase inorganic and organic acids from biomass fires by negative-ion proton-transfer chemical-ionization mass spectrometry, J. Geophys. Res., 115, D23302, doi:10.1029/2010jd014033, 2010.

Villena, G., Kleffmann, J., Kurtenbach, R., Wiesen, P., Lissi, E., Rubio, M. A., Croxatto, G., and Rappenglück, B.: Vertical gradients 
of $\mathrm{HONO}, \mathrm{No}_{\mathrm{x}}$ and $\mathrm{O}_{3}$ in Santiago de Chile, Atmos. Environ., 45, 3867-3873, doi:10.1016/j.atmosenv.2011.01.073, 2011.

Wong, K. W., Tsai, C., Lefer, B., Haman, C., Grossberg, N., Brune, W. H., Ren, X., Luke, W., and Stutz, J.: Daytime HONO vertical gradients during SHARP 2009 in Houston, TX, Atmos. Chem. Phys., 12, 635-652, doi:10.5194/acp-12-635-2012, 2012.

Zhang, N., Zhou, X., Shepson, P. B., Gao, H., Alaghmand, M., and Stirm, B.: Aircraft measurement of HONO vertical profiles over a forested region, Geophys. Res. Lett., 36, L15820, doi:10.1029/2009g1038999, 2009.

Zhang, Q. J., Beekmann, M., Drewnick, F., Freutel, F., Schneider, J., Crippa, M., Prevot, A. S. H., Baltensperger, U., Poulain, L., Wiedensohler, A., Sciare, J., Gros, V., Borbon, A., Colomb, A., Michoud, V., Doussin, J.-F., Denier van der Gon, H. A. C., Haeffelin, M., Dupont, J.-C., Siour, G., Petetin, H., Bessagnet, B., Pandis, S. N., Hodzic, A., Sanchez, O., Honoré, C., and Perrussel, O.: Formation of organic aerosol in the Paris region during the MEGAPOLI summer campaign: evaluation of the volatilitybasis-set approach within the CHIMERE model, Atmos. Chem. Phys., 13, 5767-5790, doi:10.5194/acp-13-5767-2013, 2013.
Zhou, X., Beine, H. J., Honrath, R. E., Fuentes, J. D., Simpson, W., Shepson, P. B., and Bottenheim, J. W.: Snowpack photochemical production of HONO: a major source of $\mathrm{OH}$ in the Arctic boundary layer in springtime, Geophys. Res. Lett., 28, 40874090, doi:10.1029/2001g1013531, 2001.

Zhou, X., Civerolo, K., Dai, H., Huang, G., Schwab, J., and Demerjian, K.: Summertime nitrous acid chemistry in the atmospheric boundary layer at a rural site in New York State, J. Geophys. Res., 107, 4590, doi:10.1029/2001jd001539, 2002.

Zhou, X., Gao, H., He, Y., Huang, G., Bertman, S. B., Civerolo, K., and Schwab, J.: Nitric acid photolysis on surfaces in low$\mathrm{NO}_{\mathrm{x}}$ environments: Significant atmospheric implications, Geophys. Res. Lett., 30, 2217, doi:10.1029/2003gl018620, 2003. 